Article

\title{
HDO of Methyl Palmitate over Silica-Supported Ni Phosphides: Insight into Ni/P Effect
}

\author{
Irina V. Deliy * (D), Ivan V. Shamanaev (D), Evgeny Yu. Gerasimov (D), Vera P. Pakharukova, \\ Ilya V. Yakovlev, Olga B. Lapina, Pavel V. Aleksandrov and Galina A. Bukhtiyarova
}

Boreskov Institute of Catalysis, Pr. Lavrentieva 5, 630090 Novosibirsk, Russia; i.v.shamanaev@catalysis.ru (I.V.S.); gerasimov@catalysis.ru (E.Y.G.); verapakharukova@yandex.ru (V.P.P.); spitzstichel@gmail.com (I.V.Y.); olga@catalysis.ru (O.B.L.); aleksandrov@catalysis.ru (P.V.A.); gab@catalysis.ru (G.A.B.)

* Correspondence: delij@catalysis.ru; Tel.: +7-383-326-9410

Academic Editor: Yong-Kul Lee and Keith Hohn

Received: 30 July 2017; Accepted: 30 September 2017; Published: 4 October 2017

\begin{abstract}
Two sets of silica-supported nickel phosphide catalysts with a nickel content of about 2.5 and $10 \mathrm{wt} \%$ and $\mathrm{Ni} / \mathrm{P}$ molar ratio $2 / 1,1 / 1$ and $1 / 2$ in each set, were prepared by way of a temperature-programmed reduction method using $\left(\mathrm{Ni}\left(\mathrm{CH}_{3} \mathrm{COO}\right)_{2}\right)$ and $\left(\left(\mathrm{NH}_{4}\right)_{2} \mathrm{HPO}_{4}\right)$ as a precursor. The $\mathrm{Ni}_{\mathrm{x}} \mathrm{P}_{\mathrm{y}} / \mathrm{SiO}_{2}$ catalysts were characterized using chemical analysis $\mathrm{N}_{2}$ physisorption, $\mathrm{XRD}, \mathrm{TEM}$, ${ }^{31} \mathrm{P}$ MAS NMR. Methyl palmitate hydrodeoxygenation (HDO) was performed in a trickle-bed reactor at $3 \mathrm{MPa}$ and $290{ }^{\circ} \mathrm{C}$ with LHSV ranging from 0.3 to $16 \mathrm{~h}^{-1}$. The Ni/P ratio was found to affect the nickel phosphide phase composition, $\mathrm{PO}_{\mathrm{x}}$ groups content and catalytic properties in methyl palmitate $\mathrm{HDO}$ with the TOF increased along with a decline of $\mathrm{Ni} / \mathrm{P}$ ratio and a growth of $\mathrm{PO}_{\mathrm{x}}$ groups content. Taking into account the possible routes of methyl palmitate conversion (metal-catalyzed hydrogenolysis or acid-catalyzed hydrolysis), we proposed that the enhancement of acid $\mathrm{PO}_{\mathrm{x}}$ groups content with the $\mathrm{Ni} / \mathrm{P}$ ratio decrease provides an enhancement of the rate of methyl palmitate conversion through the acceleration of acid-catalyzed hydrolysis.
\end{abstract}

Keywords: nickel phosphide; $\mathrm{Ni} / \mathrm{P}$ ratio; nickel content; $\mathrm{PO}_{\mathrm{x}}$ groups content; ${ }^{31} \mathrm{P}$ MAS NMR; acidity; hydrodeoxygenation; methyl palmitate

\section{Introduction}

Triglyceride-based feedstocks are widely studied as a resource for the production of diesel-range or aviation fuel through the hydrodeoxygenation (HDO) process using aliphatic ether or acid as model compounds [1-5]. HDO of triglycerides, fatty esters and acids produce an oxygen-free mixture of alkanes which are the valuable components compatible with petroleum-based motor fuels [6]. In recent years transition metal phosphide systems have proved to be the promising catalysts in HDO of fatty acid methyl esters [7-16], fatty acids [17] and vegetable oils [5,18] as well as in co-hydroprocessing of vegetable oils and gas oil mixture [19]. Among a number of transition metal phosphides the silica-supported nickel phosphide catalysts were found to display a higher activity in HDO of aliphatic ether [7], which is converted through the complicated scheme with the participation of acid-catalyzed and metal-catalyzed reactions $[7,12,14,15,20,21]$. Alkanes with the same number of carbon atoms and water are produced in the HDO pathways including hydrogenation-dehydrogenation and dehydration reactions; while $\mathrm{DeCO}_{\mathrm{x}}$ pathways produce alkanes with shorter carbon chains and $\mathrm{CO}_{\mathrm{x}}$ molecules via hydrogenolysis of $\mathrm{C}-\mathrm{C}$ bonds.

The catalytic activities of nickel phosphides in hydrogenation and hydrogenolysis reactions are attributed to their metallic and acidic properties [12,22-25], caused by the covalent nature of Ni-P bond in phosphides and a slight charge transfer from Ni to P [25]. Metal phosphides contain weak 
Brønsted and Lewis acid sites attributed to the presence of unreduced $\mathrm{PO}_{\mathrm{x}}$ groups and the metal sites with small positive charge, respectively $[7,26-28]$. The various aspects of preparation technique, such as precursor nature, reduction temperature, metal content and $\mathrm{Ni} / \mathrm{P}$ ratio were observed to affect the physicochemical and catalytic properties of the $\mathrm{Ni}_{x} \mathrm{P}_{y} / \mathrm{SiO}_{2}$ catalyst [24,29-32].

It was stated that the initial $\mathrm{Ni} / \mathrm{P}$ molar ratio has a profound effect on the structure and catalytic activity of the supported nickel phosphide catalysts obtained with a conventional preparation method by temperature-programmed reduction (TPR) of nickel phosphate precursors $[7,8,12,17,18,29,31,33]$. Stinner et al. [29] have reported that $\mathrm{Ni} / \mathrm{P}$ molar ratio equal to 2 leads to the formation of $\mathrm{Ni}_{12} \mathrm{P}_{5}$ and $\mathrm{Ni}_{3} \mathrm{P}$ phases over silica, $\mathrm{Ni} / \mathrm{P}$ molar ratio equal to 1.7 leads to $\mathrm{Ni}_{12} \mathrm{P}_{5}$ and $\mathrm{Ni}_{2} \mathrm{P}$ phases, and $\mathrm{Ni} / \mathrm{P}$ molar ratio $=1.5$ favors $\mathrm{Ni}_{2} \mathrm{P}$ phase only.

Chen et al. [7] studied the silica-supported nickel phosphide catalysts with different $\mathrm{Ni} / \mathrm{P}$ molar ratios in methyl laurate HDO. It was observed that the catalytic activity of obtained catalysts followed the order:

$$
\mathrm{Ni}_{3} \mathrm{P}(\mathrm{Ni} / \mathrm{P}=3 / 1)<\mathrm{Ni}_{12} \mathrm{P}_{5}(\mathrm{Ni} / \mathrm{P}=2 / 1)<\mathrm{Ni}_{2} \mathrm{P}(\mathrm{Ni} / \mathrm{P}=1 / 1 \text { and } 1 / 2) \approx \mathrm{Ni}
$$

Yang et al. [8] investigated the influence of $\mathrm{Ni} / \mathrm{P}$ molar ratios on the performance of $\mathrm{Ni}_{\mathrm{x}} \mathrm{P}_{\mathrm{y}} / \mathrm{SBA}-15$ catalysts in methyl oleate $\mathrm{HDO}$. It was shown that $\mathrm{Ni}_{2} \mathrm{P} / \mathrm{SBA}-15$ catalyst with $\mathrm{Ni} / \mathrm{P}=1 / 1$ presents the highest catalytic activity; the catalytic activity of nickel phosphide catalysts in methyl oleate HDO followed the order:

$$
\mathrm{Ni}_{3} \mathrm{P}(\mathrm{Ni} / \mathrm{P}=3 / 1)<\mathrm{Ni}_{12} \mathrm{P}_{5}(\mathrm{Ni} / \mathrm{P}=2 / 1) \approx \mathrm{Ni}_{2} \mathrm{P}(\mathrm{Ni} / \mathrm{P}=1 / 2)<\mathrm{Ni}_{2} \mathrm{P}(\mathrm{Ni} / \mathrm{P}=1 / 1) .
$$

It was mentioned that the catalytic activity of Ni/SBA-15 catalyst is slightly higher than demonstrated by any of the similar prepared $\mathrm{Ni}_{2} \mathrm{P} / \mathrm{SBA}-15$ samples in methyl oleate HDO [8,9]. Guan et al. [10] and Xue et al. [11] showed the opposite results on methyl palmitate HDO in the presence of $\mathrm{Ni} / \mathrm{SiO}_{2}$ and $\mathrm{Ni}_{2} \mathrm{P} / \mathrm{SiO}_{2}$ catalysts. It was pointed [10] that $\mathrm{Ni}_{2} \mathrm{P} / \mathrm{SiO}_{2}$ showed significantly higher activity in comparison with $\mathrm{Ni} / \mathrm{SiO}_{2}$ in terms of methyl palmitate conversion. The catalytic activity of the $\mathrm{Ni}_{\mathrm{x}} \mathrm{P}_{\mathrm{y}} / \mathrm{SiO}_{2}$ catalysts depending on $\mathrm{Ni} / \mathrm{P}$ ratios increases in the order:

$$
\mathrm{Ni}_{2} \mathrm{P}(\mathrm{Ni} / \mathrm{P}=1 / 1.5)<\mathrm{Ni}_{2} \mathrm{P}(\mathrm{Ni} / \mathrm{P}=1 / 1.75)<\mathrm{Ni}_{2} \mathrm{P}(\mathrm{Ni} / \mathrm{P}=1 / 2)<\mathrm{Ni}_{2} \mathrm{P} \text { and } \mathrm{Ni}_{5} \mathrm{P}_{4}(\mathrm{Ni} / \mathrm{P}=1 / 2.5) \text {. }
$$

The above-cited articles demonstrate discrepancy in the results concerning the effect of $\mathrm{Ni} / \mathrm{P}$ ratio on the catalytic properties of nickel phosphide catalysts in methyl ethers HDO. Nearly the same activities in methyl laurate HDO were reported by Chen et al. [7] for the catalysts with the Ni/P ratios $1 / 1$ and $1 / 2$ indicating negligible effect at $\mathrm{Ni} / \mathrm{P}<1$; according to Yang et al. [8] the highest activity in methyl oleate $\mathrm{HDO}$ was displayed by the catalyst with $\mathrm{Ni} / \mathrm{P}=1 / 1$. And, finally, a gradual increase in catalytic activity was observed in the study of Guan at el. [10] with the decrease of Ni/P ratio from $1 / 1.15$ to $1 / 2.5$. This discrepancy can be explained by the use of catalysts with the different metal loading, mean particle sizes or wide particle size distribution, which could have influenced the catalytic activity. The scarce data on size effect are also rather contradictory. According to data reported by Guan et al. [13] the particle size increase of MCM-41 supported nickel phosphide has no influence on TOF of methyl palmitate conversion. Yang et al. [14] reported that the TOF increased with the $\mathrm{Ni}_{2} \mathrm{P}$ crystallite size in the methyl laurate HDO.

To reach a better insight into the $\mathrm{Ni} / \mathrm{P}$ effect on the catalytic properties of silica-supported nickel phosphide catalysts in methyl palmitate $\mathrm{HDO}$ two sets of $\mathrm{Ni}_{\mathrm{x}} \mathrm{P}_{\mathrm{y}} / \mathrm{SiO}_{2}$ catalysts differing in Ni content and $\mathrm{Ni} / \mathrm{P}$ ratio were used in the present study [15]. The low-loaded catalysts (about $2.5 \mathrm{wt} \%$ of nickel) with nearly the same mean particle size are the appropriate candidates for the comparison of specific activities of the $\mathrm{Ni}_{x} \mathrm{P}_{\mathrm{y}} / \mathrm{SiO}_{2}$ catalysts with the $\mathrm{Ni} / \mathrm{P}$ ratios 2:1, 1:1 and 1:2. The high-loaded samples (about $9-10 \mathrm{wt} \%$ of nickel) were used to follow the evolution of the active phase with the 
$\mathrm{Ni} / \mathrm{P}$ decrease the X-Ray Diffraction (XRD), transmission electron microscopy (TEM) and $\mathrm{P}^{31}$ nuclear magnetic resonance (NMR) techniques were employed.

\section{Results and Discussion}

\subsection{Catalysts Characterization}

Two sets of the $\mathrm{Ni}_{x} \mathrm{P}_{\mathrm{y}} / \mathrm{SiO}_{2}$ catalysts were prepared with different initial Ni/P molar ratios and nickel content in each series in the range of $2.5-2.9 \mathrm{wt} \%$ (denoted as low-loaded samples, $l-\mathrm{Ni}_{\mathrm{x}} \mathrm{P}_{\mathrm{y}}$ ) or $9.0-10.9 \mathrm{wt} \%$ (denoted as high-loaded samples, $h-\mathrm{Ni}_{\mathrm{x}} \mathrm{P}_{\mathrm{y}}$ ). For the preparation of each set of the catalysts the solutions of nickel acetate $\left(\mathrm{Ni}\left(\mathrm{CH}_{3} \mathrm{COO}\right)_{2}\right)$ and di-ammonium hydrogen phosphate $\left(\left(\mathrm{NH}_{4}\right)_{2} \mathrm{HPO}_{4}\right)$ were used, containing the adjusted amount of $\mathrm{Ni}$ and different initial $\mathrm{Ni} / \mathrm{P}$ molar ratios of $2 / 1 ; 1 / 1$ or $1 / 2$. The obtained samples were denoted as $h$-Ni2P1, $h$-Ni1P1, $h$-Ni1P2 and $l$-Ni2P1, l-Ni1P1, l-Ni1P2, correspondingly.

Recently Shamanaev et al. [16] established the optimal reduction conditions for the silica-supported nickel phosphide catalysts displaying the highest catalytic activity in methyl palmitate hydrodeoxygenation. On the basis of our previous results $[15,16]$ and the literature data reported for the phosphate-containing type of precursors [13,34-36] the reduction temperature of $600{ }^{\circ} \mathrm{C}$ was chosen in this study for catalysts preparation. The physicochemical properties of the $\mathrm{Ni}_{\mathrm{x}} \mathrm{P}_{\mathrm{y}} / \mathrm{SiO}_{2}$ catalysts as well as $\mathrm{PO}_{x} / \mathrm{SiO}_{2}$ reference sample, and $\mathrm{SiO}_{2}$ support are summarized in Table 1 .

Table 1. Physicochemical properties of $\mathrm{Ni}_{x} \mathrm{P}_{y} / \mathrm{SiO}_{2}$ catalysts as well as the reference samples $\mathrm{Ni} / \mathrm{SiO}_{2}$, $\mathrm{PO}_{\mathrm{x}} / \mathrm{SiO}_{2}$ and $\mathrm{SiO}_{2}$ support.

\begin{tabular}{|c|c|c|c|c|c|c|c|}
\hline Sample & $\mathrm{Ni}$, wt $\%$ & P, wt \% & $\begin{array}{l}\text { Ni/P Molar Ratio } \\
\text { after TPR }\end{array}$ & $\begin{array}{l}A_{\text {BET }} \\
\mathrm{m}^{2} / g\end{array}$ & $\begin{array}{c}\mathrm{D}_{\text {pore }} \\
\mathrm{nm}\end{array}$ & $\begin{array}{l}D_{S} \text { after } \\
T P R, n m\end{array}$ & $\begin{array}{c}\text { X-ray } \\
\text { Diffraction } \\
\text { (XRD) Phase }\end{array}$ \\
\hline $\mathrm{SiO}_{2}$ & - & - & - & 300 & 10.6 & - & - \\
\hline $\mathrm{PO}_{\mathrm{x}} / \mathrm{SiO}_{2}$ & - & 5.31 & - & 200 & 10.8 & - & - \\
\hline$h-\mathrm{Ni}$ & 8.6 & - & - & 215 & 10.5 & & $\mathrm{Ni}$ \\
\hline$h$-Ni2P1 & 10.9 & 2.4 & 2.4 & 195 & 11.7 & & $\mathrm{Ni}_{12} \mathrm{P}_{5}$ \\
\hline$h$-Ni1P1 & 10.3 & 3.6 & 1.5 & 190 & 10.4 & & $\mathrm{Ni}_{2} \mathrm{P}$ \\
\hline$h$-Ni1P2 & 9.0 & 5.0 & 0.9 & 175 & 10.3 & & $\mathrm{Ni}_{2} \mathrm{P}$ \\
\hline l-Ni2P1 & 2.9 & 0.8 & 2.1 & 290 & 10.1 & $4.9 \pm 1.3$ & $\mathrm{Ni}_{12} \mathrm{P}_{5}$ \\
\hline l-Ni1P1 & 2.8 & 1.4 & 1.1 & 270 & 10.3 & $4.7 \pm 1.1$ & $\mathrm{Ni}_{2} \mathrm{P}$ \\
\hline l-Ni1P2 & 2.5 & 1.9 & 0.7 & 255 & 10.5 & $3.5 \pm 0.9$ & $\mathrm{Ni}_{2} \mathrm{P}$ \\
\hline
\end{tabular}

According to the elemental analysis by ICP-AES, the Ni content in reduced samples varied from 2.5 to $2.9 \mathrm{wt} \%$ for the low-loaded set of samples $\left(l-\mathrm{Ni}_{\mathrm{x}} \mathrm{P}_{\mathrm{y}}\right)$ and from 8 to $11 \mathrm{wt} \%$ for the high- loaded set of samples $\left(h-\mathrm{Ni}_{\mathrm{x}} \mathrm{P}_{\mathrm{y}}\right)$. It was stated that the $\mathrm{Ni} / \mathrm{P}$ molar ratios in reduced catalysts were higher than the initial $\mathrm{Ni} / \mathrm{P}$ molar ratios in oxide precursors and impregnating solutions. The increase of the $\mathrm{Ni} / \mathrm{P}$ molar ratio in the samples after reduction is caused by the formation of volatile phosphorus-containing species (namely $\mathrm{PH}_{3}, \mathrm{P}_{2} \mathrm{P}_{2}$ etc.) during high-temperature reduction as it has been reported earlier [31].

The textural parameters of the reduced catalysts have been obtained from the $\mathrm{N}_{2}$ adsorption-desorption isotherms (Table 1$)$. The BET specific surface areas $\left(\mathrm{A}_{\mathrm{BET}}\right)$ of the low-loaded set of samples decrease slightly with nickel phosphide loading in comparison with the pure $\mathrm{SiO}_{2}$ support $\left(255-290 \mathrm{~m}^{2} / \mathrm{g}\right.$ vs. $300 \mathrm{~m}^{2} / \mathrm{g}$ of $\left.\mathrm{SiO}_{2}\right)$; the decrease of the BET surface areas for the high-loaded set of samples is more pronounced (175-195 $\left.\mathrm{m}^{2} / \mathrm{g}\right)$, indicating the partial coverage and/or clogging of the inner pore space of the catalysts by the nickel phosphide particles and residues of the phosphorus-containing compounds (unreduced $\mathrm{PO}_{\mathrm{x}}$ groups [30,37], elemental $\mathrm{P}_{4}$ and $\mathrm{P}_{2}$ [29]). It was observed that with decreasing of the $\mathrm{Ni} / \mathrm{P}$ ratio in each set of the reduced catalysts, the surface area and pore volume tended to decrease because of the surplus phosphorus-containing species on 
silica surface $[29,38]$. The average pore diameters for the $l-\mathrm{Ni}_{\mathrm{x}} \mathrm{P}_{\mathrm{y}}$ and $h-\mathrm{Ni}_{\mathrm{x}} \mathrm{P}_{\mathrm{y}}$ sets of catalysts do not changed noticeably (Table 1).

The formation of nickel phosphide particles on silica surface after temperature-programmed reduction (TPR) was proved by XRD, TEM and ${ }^{31}$ P-MAS NMR methods. The $X$-ray diffraction patterns of reduced $\mathrm{Ni}_{x} \mathrm{P}_{\mathrm{y}} / \mathrm{SiO}_{2}$ catalysts and $\mathrm{SiO}_{2}$ support are presented in Figure 1. XRD pattern of the initial $\mathrm{SiO}_{2}$ support (Figure 1a) contains a broad peak centered at $2 \theta \sim 22^{\circ}$, which corresponds to amorphous $\mathrm{SiO}_{2}$ and can be seen in all of the represented XRD patterns of the $\mathrm{Ni}_{\mathrm{x}} \mathrm{P}_{\mathrm{y}} / \mathrm{SiO}_{2}$ catalysts. Figure 1 a shows the XRD patterns of the high-loaded $h$-Ni2P1 and low-loaded $l$-Ni2P1 samples that were prepared to start with the initial Ni/P molar ratio equal to 2/1. Apart from the diffraction peak related to the support, the characteristic peaks at $2 \theta=32.6^{\circ}, 38.4^{\circ}, 41.7^{\circ}, 44.4^{\circ}, 46.9^{\circ}$ and $48.9^{\circ}$ of the $\mathrm{Ni}_{12} \mathrm{P}_{5}$ phase $\left(\mathrm{a}=\mathrm{b}=8.646 \AA, \mathrm{c}=5.070 \AA, \alpha=\beta=\gamma=90^{\circ}\right.$; JCPDS \#22-1190) are fixed in the diffraction patterns of Ni2P1 samples. The estimation of $\mathrm{Ni}_{12} \mathrm{P}_{5}$ crystallites size ( $\left.\mathrm{D}_{\mathrm{XRD}}\right)$ on the surface of the high-loaded $h$-Ni2P1 sample gives about $16.0 \mathrm{~nm}$, whereas the XRD pattern of low-loaded $l$-Ni2P1 sample contains very weak and broadened reflections from $\mathrm{Ni}_{12} \mathrm{P}_{5}$ phase, suggesting that this phase should be highly dispersed (Figure 1a). That makes difficult the correct determination of DXRD for l-Ni2P1 sample.

Figure $1 \mathrm{~b}$ shows the XRD patterns of the high-loaded $h$-Ni1P1 and low-loaded $l$-Ni1P1 samples prepared with equimolar initial Ni/P ratio. All of represented XRD patterns of Ni1P1 catalysts contain the characteristic peaks at $2 \theta=40.6^{\circ}, 44.5^{\circ}, 47.1^{\circ}, 54.1^{\circ}, 54.8^{\circ}, 66.1^{\circ}, 72.5^{\circ}$ and $74.5^{\circ}$ of the $\mathrm{Ni}_{2} \mathrm{P}$ phase $\left(\mathrm{a}=\mathrm{b}=5.859 \AA, \mathrm{c}=3.382 \AA, \alpha=\beta=90^{\circ}, \gamma=120^{\circ}\right.$; JCPDS \#03-0953) with $\mathrm{D}_{\mathrm{XRD}}=13 \mathrm{~nm}$ for $h$-Ni1P1 sample. The XRD patterns of the high-loaded $h$-Ni1P2 and low-loaded $l$-Ni1P2 samples prepared with the lower initial molar $\mathrm{Ni} / \mathrm{P}=1 / 2$ are displayed in Figure $1 \mathrm{c}$. The $\mathrm{Ni}_{2} \mathrm{P}$ phase characteristic peaks are revealed in the diffraction patterns of Ni1P2 samples with the estimated $\mathrm{Ni}_{2} \mathrm{P}$ crystallites size equal to $\mathrm{D}_{\mathrm{XRD}}=10 \mathrm{~nm}$ in the $h$-Ni1P2 sample. The diffraction patterns corresponding to $l$-Ni1P2 samples exhibits the broadened diffraction lines with a lower intensity indicating the presence of the highly dispersed $\mathrm{Ni}_{2} \mathrm{P}$ phase. Also, as for the other low-loaded samples, it is hardly possible to estimate $\mathrm{D}_{\mathrm{XRD}}$ for $l$-Ni1P2 sample from the XRD data correctly.

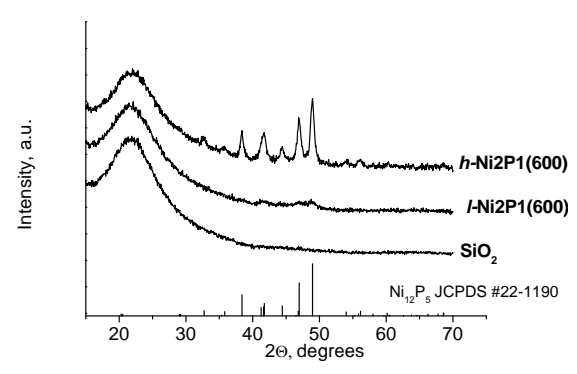

(a)

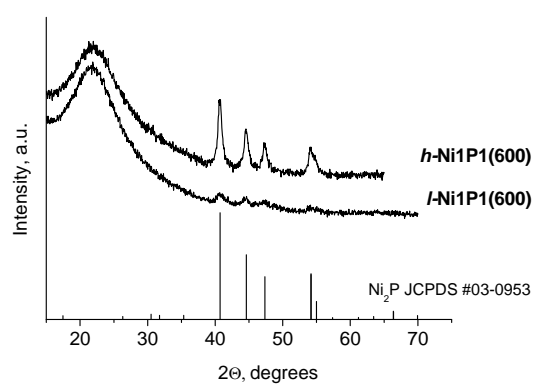

(b)

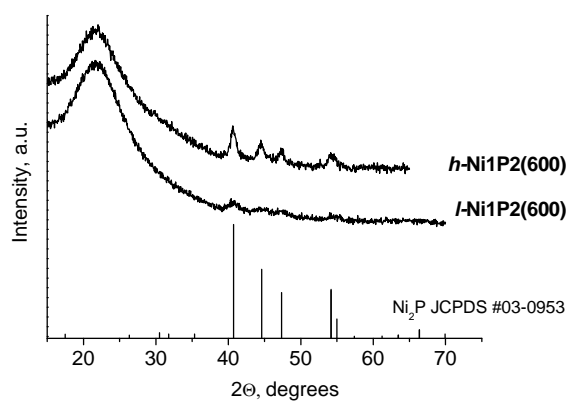

(c)

Figure 1. XRD patterns of silica-supported $\mathrm{Ni}_{\mathrm{x}} \mathrm{P}_{\mathrm{y}}$ catalysts and $\mathrm{SiO}_{2}$ support: (a) $h-\mathrm{Ni} 2 \mathrm{P} 1, l-\mathrm{Ni} 2 \mathrm{P} 1$ and $\mathrm{SiO}_{2} ;$ (b) $h$-Ni1P1 and $l$-Ni2P1; (c) $h$-Ni1P2, $l$-Ni1P2. 
Thus, the XRD data are shown in Table 1 and Figure 1 clearly demonstrate that the initial $\mathrm{Ni} / \mathrm{P}$ molar ratio influences crystalline phase composition of the reduced phosphide catalysts. The initial Ni/P molar ratio of $2 / 1$ favors formation of $\mathrm{Ni}_{12} \mathrm{P}_{5}$ phase. Further increasing the amount of phosphorus to $\mathrm{Ni} / \mathrm{P}=1 / 1$ and $1 / 2$ led to the formation of the $\mathrm{Ni}_{2} \mathrm{P}$ phase. A similar dependence of nickel phosphide crystalline phase on the initial $\mathrm{Ni} / \mathrm{P}$ molar ratio for silica-supported nickel phosphide catalysts has been observed previously for phosphate precursor $[7,8,37,38]$. The initial excess of $\mathrm{P}$ content in the precursors was shown to be the prerequisite of the $\mathrm{Ni}_{2} \mathrm{P}$ phase formation $[7,8,30,31,37,38]$.

The increase of phosphorus precursor content in the $\mathrm{Ni}_{2} \mathrm{P} / \mathrm{SiO}_{2}$ catalysts leads to a higher dispersion of nickel phosphide particles on a silica support. The nickel phosphide crystallite sizes for the high-loaded set of the samples diminishes in the row: $h$-Ni2P1 $(16.0 \mathrm{~nm})>h$-Ni1P1 $(13.0 \mathrm{~nm})>$ $h$-Ni1P2 (10.0 nm). Probably the initial nickel phosphate precursor was surrounded with an excess of polymeric phosphate species preventing the aggregation during the calcination step and favoring the higher dispersion of resulting nickel phosphide particles [31].

The TEM images of two sets of the $\mathrm{Ni}_{\mathrm{x}} \mathrm{P}_{\mathrm{y}} / \mathrm{SiO}_{2}$ catalysts with different initial Ni/P molar ratios are shown in Figure 2a-f. The nickel phosphide particles with different size ranged in the regions from 2.0 to $20 \mathrm{~nm}$ were observed in the high-loaded $h$-Ni2P1, $h$-Ni1P1 and $h$-Ni1P2 samples (Figure 2a-c). Besides, several particles with the size up to $50 \mathrm{~nm}$ were found. The observed wide particle size distribution makes it difficult to estimate correctly the average size of particles by statistical analysis of the TEM patterns of $h-\mathrm{Ni}_{\mathrm{x}} \mathrm{P}_{\mathrm{y}}$ samples. The TEM images of the low-loaded $l$-Ni2P1, $l$-Ni1P1, and $l$-Ni1P2 catalysts (Figure $2 \mathrm{~d}-\mathrm{f}$ ) show the nickel phosphide particles with a narrow particle size distribution; the mean particle surface diameters $\left(\mathrm{D}_{\mathrm{s}}\right)$ are $4.9 \pm 1.3 \mathrm{~nm}$ for $l$-Ni2P1, $4.7 \pm 1.1 \mathrm{~nm}$ for $l$-Ni1P1 and $3.5 \pm 0.9 \mathrm{~nm}$ for $l$-Ni1P2. The TEM image of $l$-Ni2P1 sample (see Figure S1a in Supplementary Materials) reveals crystal lattice fringes with the d-spacing value of $2.20 \AA, 2.47 \AA$, and $2.74 \AA$ corresponding to the (202), (112) and (220) reflections of the $\mathrm{Ni}_{12} \mathrm{P}_{5}$ phase (JCPDS \#22-1190), respectively. The TEM images of $l$-Ni1P1 and $l$-Ni1P2 samples in Figures S1b and S1c in Supplementary Materials exhibit crystal lattice fringes with the d-spacing value of $2.24 \AA, 2.05 \AA$, and $1.92 \AA$ corresponding to the (111), (201), and (120) reflections of the $\mathrm{Ni}_{2} \mathrm{P}$ crystalline phase (JCPDS \#03-0953).

To explore the nature of the phosphorus species on the reduced nickel phosphide catalysts the ${ }^{31}$ P MAS NMR technique was employed. Prior to NMR experiments, nickel phosphide catalysts after reduction by the conventional TPR procedure at $600{ }^{\circ} \mathrm{C}$ were transferred into ampoules and further to NMR rotor in a glove box under argon atmosphere to avoid the contact with air. This technique helps to avoid possible oxidation of nickel phosphide during NMR spectra acquisition. Figure 3 demonstrates a spin-echo ${ }^{31} \mathrm{P} 14 \mathrm{kHz}$ MAS NMR spectra of the high-loaded $h$-Ni2P1, $h$-Ni1P1 and $h$-Ni1P2 catalysts with different initial Ni/P molar ratio. Two main regions of the spectra of all the measured nickel phosphide catalysts can be highlighted. The first region from +500 to $+5000 \mathrm{ppm}$ corresponds to Ni-P intermetallic compounds such as $\mathrm{Ni}_{12} \mathrm{P}_{5}, \mathrm{Ni}_{3} \mathrm{P}, \mathrm{Ni}_{2} \mathrm{P}, \mathrm{NiP}$, and $\mathrm{Ni}_{5} \mathrm{P}_{4}[15,29,39]$ and the second one from +4 to $-40 \mathrm{ppm}$ corresponds to the different phosphate species (denoted in this study overall as $\mathrm{PO}_{x}$ groups), i.e., phosphoric acid $\mathrm{H}_{n} \mathrm{PO}_{4}{ }^{(3-\mathrm{n})-}(\sim 0 \mathrm{ppm})$, terminal $\mathrm{P}_{2} \mathrm{O}_{7}{ }^{4-}(\sim-7 \mathrm{ppm})$, and internal $\left(\mathrm{PO}_{3}{ }^{-}\right)_{\mathrm{n}}(\sim-22 \mathrm{ppm})$ phosphate groups in phosphoric acid oligomers $[15,29,32,40,41]$. For all of the applied catalysts, we detected the lack of the signals with chemical shifts from -30 to $-50 \mathrm{ppm}$ that could be attributed to phosphorus-containing species in the form of silicon phosphate [40]. 


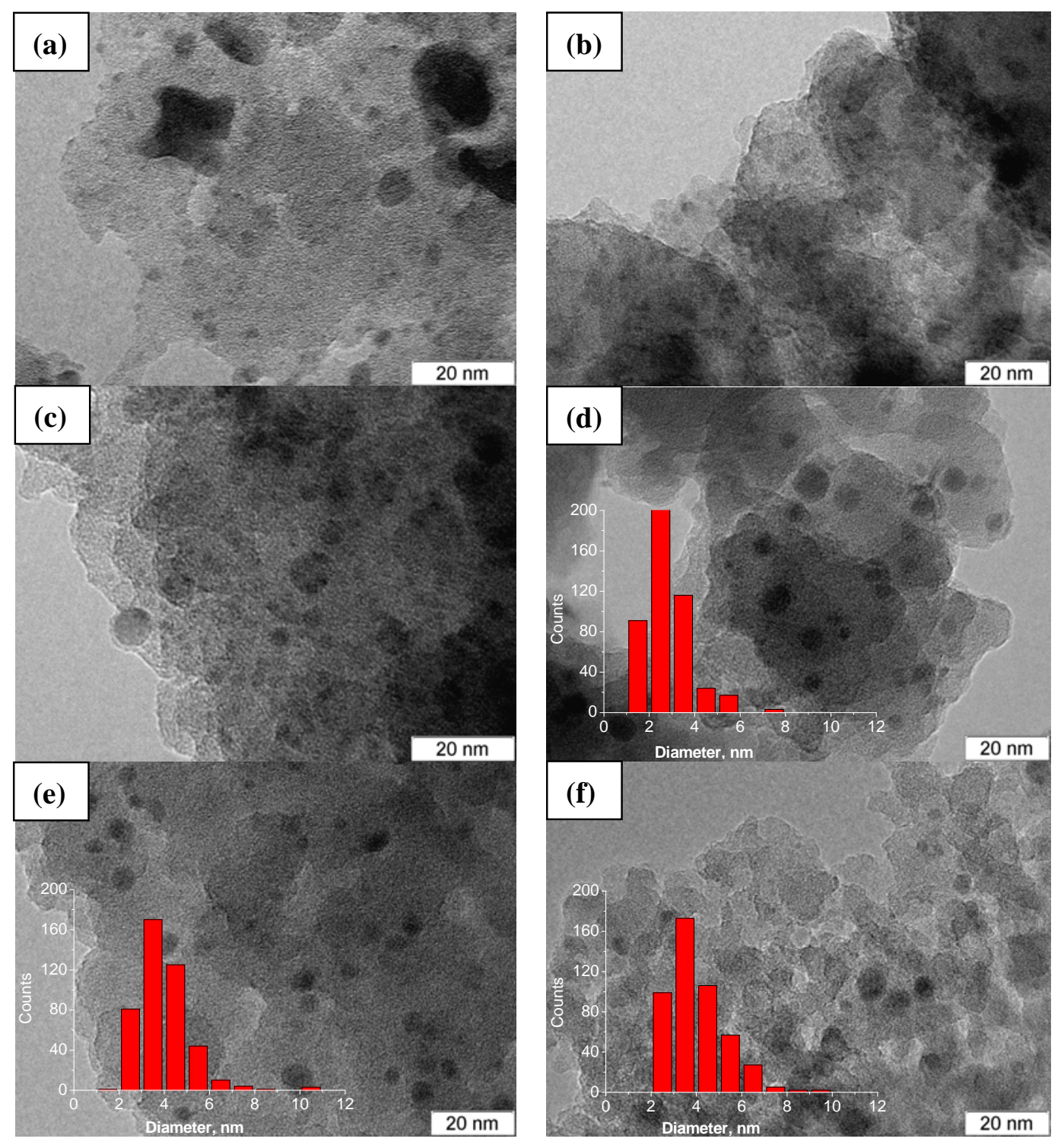

Figure 2. TEM images of $\mathrm{Ni}_{\mathrm{x}} \mathrm{P}_{\mathrm{y}} / \mathrm{SiO}_{2}$ catalysts with different initial molar Ni/P ratio: (a) $h$-Ni2P1; (b) $h$-Ni1P1; (c) $h$-Ni1P2; (d) $l$-Ni2P1; (e) $l$-Ni1P1; (f) $l$-Ni1P2.

The ${ }^{31} \mathrm{P}$ NMR spectrum of $h$-Ni2P1 sample in Figure 3 shows two well-resolvable signals with isotropic chemical shifts at $\sim 1950$ and $\sim 2250 \mathrm{ppm}$ corresponding to $\mathrm{Ni}_{12} \mathrm{P}_{5}$ phase [29]. This observation agrees with the crystalline structure identified by XRD (Table 1). Also, the additional signals from other Ni-P intermetallic compounds at 900-1500 ppm chemical shifts region are revealed in the spectrum of $h$-Ni2P1 sample. However, the amount of this new phase is negligible (since the exact line shape of $\mathrm{Ni}_{12} \mathrm{P}_{5}$ is not known the precise ratio cannot be extracted). The amount of the phosphorus species in the form of $\mathrm{PO}_{\mathrm{x}}$ groups $\left(\omega\left(\mathrm{PO}_{\mathrm{x}}\right)\right)$ was determined from the intensities of signals in the chemical shifts region from +4 to $-40 \mathrm{ppm}$. It was found that $\omega\left(\mathrm{PO}_{\mathrm{x}}\right)=3.5$ at $\%$ for $h$-Ni2P1 sample.

The $\mathrm{Ni}_{2} \mathrm{P}$ structure contains two crystallographic $\mathrm{P}$ sites and consequently gives two resonances with isotropic chemical shifts of 1487 and $4076 \mathrm{ppm}$ [29]. The ${ }^{31} \mathrm{P}$ NMR spectra of $h$-Ni1P1 and $h$-Ni1P2 samples in Figure 3 show two signals with isotropic chemical shifts at $\sim 1500$ and $\sim 4050 \mathrm{ppm}$, confirming the $\mathrm{Ni}_{2} \mathrm{P}$ phase formation. The observed broad signal with a maximum at $\sim 1500 \mathrm{ppm}$ is not symmetric, most probably due to the superposition of several signals, the NMR line shape effects could also be a reason. The maximum at $\sim 1500 \mathrm{ppm}$ is most likely to corresponds to $\mathrm{Ni}_{2} \mathrm{P}$ phase; nevertheless, the presence of other Ni-P intermetallic compounds as $\mathrm{Ni}_{12} \mathrm{P}_{5}, \mathrm{Ni}_{3} \mathrm{P}, \mathrm{NiP}$, and $\mathrm{Ni}_{5} \mathrm{P}_{4}[29,39]$ cannot be 
avoided since their chemical shifts lie in the same region and the large full width at a half maximum (FWHM) does not provide good separation of the lines. The large FWHM can be a result of either small particle or inhomogeneous character (defectiveness) of Ni-P intermetallic compounds.

The $h$-Ni1P1 sample shows two different phosphorus sites of $\mathrm{Ni}_{2} \mathrm{P}$ in contrast to $h$-Ni1P2 sample for which both the lines are highly broadened. The downfield line shoulder is not observed in $h$-Ni1P1 sample either. Moreover, the line FWHM is narrower, which causes observation of spinning sidebands. It was found that the characteristic lines at $\sim 1500$ and $\sim 4050 \mathrm{ppm}$ in ${ }^{31} \mathrm{P}$ NMR spectrum of $h$-Ni1P1 sample are narrower than those for $h$-Ni1P2 sample probably because of smaller amount of stacking faults in $h$-Ni1P1 sample or larger average nickel phosphide particle size that leads to presence of some amount of large particles with well-formed $\mathrm{Ni}_{2} \mathrm{P}$ phase giving rise to sharp peaks on the spectrum. The estimated values of $\omega\left(\mathrm{PO}_{\mathrm{x}}\right)$ are equal to 10.0 and 13.0 at \% of total phosphorus for $h$-Ni1P1 and for $h$-Ni1P2 samples correspondingly. It is necessary to mention that ${ }^{31} \mathrm{P}$ NMR spectrum of low-loaded $l$-NiP2 sample resembles the spectrum of $h$-Ni1P2 catalyst, but intensities of the peaks in the low-loaded sample are noticeably lower, which makes questionable the quantitative estimation of the amount of $\mathrm{PO}_{\mathrm{x}}$ groups.

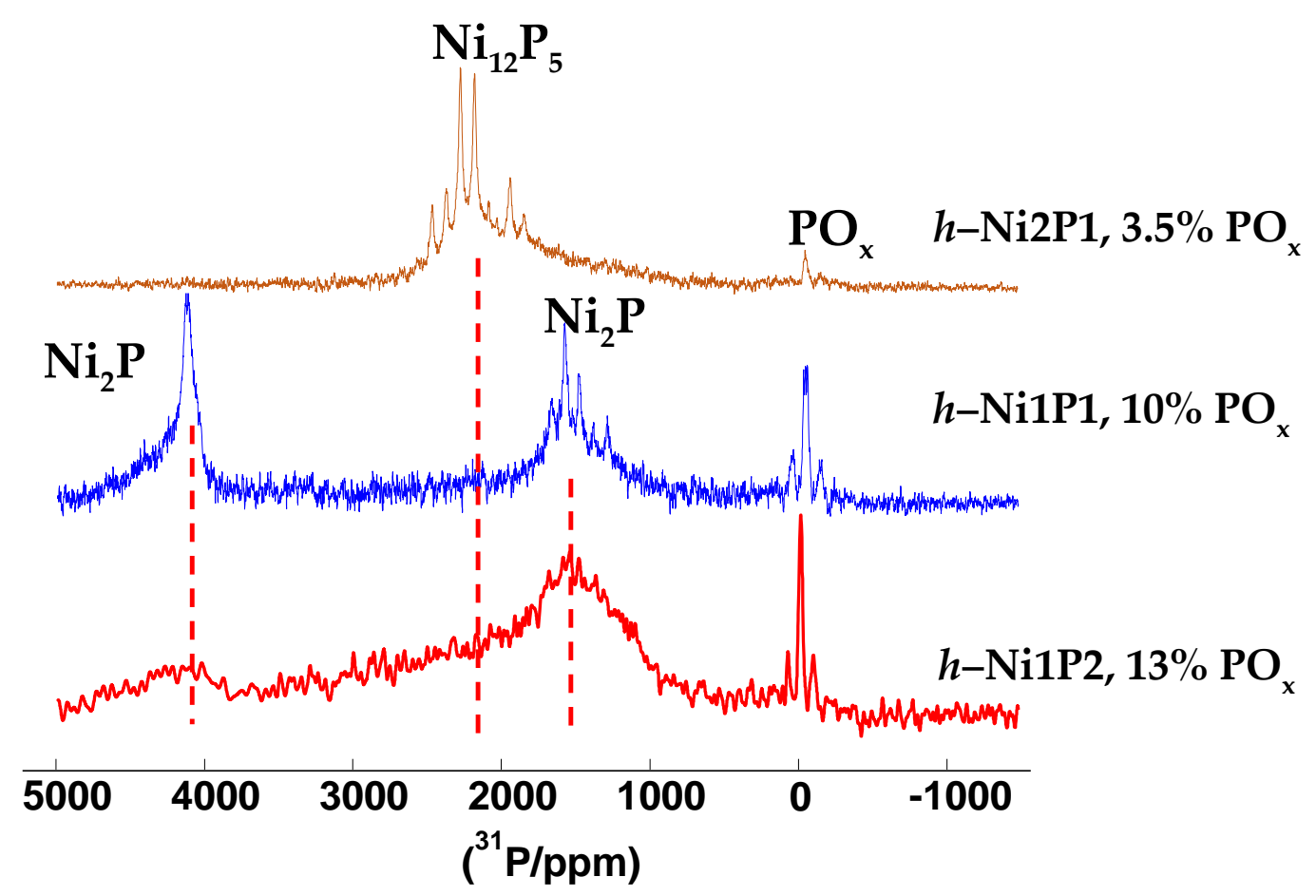

Figure 3. Spin-echo ${ }^{31} \mathrm{P} 14 \mathrm{kHz}$ MAS NMR spectra of high-loaded $\mathrm{Ni}_{\mathrm{x}} \mathrm{P}_{\mathrm{y}} / \mathrm{SiO}_{2}$ catalysts with different initial Ni/P molar ratio $\left(2 / 1,1 / 1\right.$ and $1 / 2$ top-down) reduced at $600^{\circ} \mathrm{C}$. Spectra are normalized to the same amplitude of the highest point.

Summarizing the XRD, TEM and NMR results of catalysts characterization the several conclusions have to be indicated. XRD and ${ }^{31} \mathrm{P}$ MAS NMR data showed that the initial Ni/P molar ratio influences on phase composition of reduced phosphide catalysts: $\mathrm{Ni}_{2} \mathrm{P}$ is produced using the initial $\mathrm{Ni} / \mathrm{P}$ molar ratio of 1 and 0.5 , while the initial $\mathrm{Ni} / \mathrm{P}$ molar ratio of 2 favors formation of $\mathrm{Ni}_{12} \mathrm{P}_{5}$ phase in accordance with the previous results $[7,8,37,38]$. The TEM data showed that high-loaded samples ( $h$-Ni2P1, $h$-Ni1P1, and $h$-Ni1P2) contain phosphide particles with the broad particle size distribution (from 2 to $20 \mathrm{~nm}$ ). On the contrary, the TEM images of the low-loaded samples demonstrated uniformly distributed phosphide particles with approximately the same mean particle diameter. ${ }^{31} \mathrm{P}$ MAS NMR results let us estimate the portion of $\mathrm{P}$ entering in the $\mathrm{PO}_{\mathrm{x}}$ groups on the surface of high-loaded samples, showing the enrichment of the catalysts with phosphate species as the $\mathrm{Ni} / \mathrm{P}$ ratio decreases. 
Unfortunately, such estimation cannot be done in the case of the low-loaded samples due to the low intensity of the ${ }^{31} \mathrm{P}$ MAS NMR signals. Previously it was stated that namely the $\mathrm{PO}_{\mathrm{x}}$ groups are responsible for the Brønsted acidity of $\mathrm{Ni}_{x} \mathrm{P}_{y} / \mathrm{SiO}_{2}$ catalysts $[7,26,28,37,42,43]$.

The obtained set of low-loaded samples are the appropriate candidates for comparing catalytic behavior in methyl palmitate hydrodeoxygenation due to approximately the same mean particle diameters and narrow particle size distributions of the nickel phosphide on silica. At the same time, high-loaded samples provide a reliable insight into the nature of the active phase in nickel phosphide catalysts.

\subsection{Catalytic Performance of Nickel and Nickel Phosphide Catalysts}

\subsubsection{Mass-Transfer Process in Methyl Palmitate HDO}

In order to evaluate the effect of internal diffusion on catalytic HDO, the Weisz-Prater criterion was used [44]. For negligible diffusional limitations the Weisz-Prater number estimated by equations is less than 0.3:

$$
N_{W-P}=\frac{A_{M . S .} \cdot R_{\text {particles }}^{2}}{C_{S} \cdot D_{\text {eff }}} \leq 0.3
$$

where $A_{\text {M.S. }}$ is the observed reaction rate, $R_{\text {particles }}$ is the catalyst particles radius, $C_{s}$ is the reactant surface concentration and $D_{\text {eff }}$ is the effective diffusion coefficient. The details of the procedure used for calculation of the Weisz-Prater numbers in case of methyl palmitate HDO was described previously in reference [15]. The Weisz-Prater numbers for hydrogen and methyl palmitate for the most active high-loaded $h$-Ni1P2 sample in methyl palmitate HDO were found at a temperature of $290{ }^{\circ} \mathrm{C}$, hydrogen pressure $3.0 \mathrm{MPa}, \mathrm{H}_{2} /$ feed volume ratio $600 \mathrm{Nm}^{3} / \mathrm{m}^{3}$ and LHSV of $10.7 \mathrm{~h}^{-1}$. The values of $N_{W-P ~ H 2}=0.02$ and $N_{W-P} M P=0.16$ indicate the negligible internal mass transfer effects on HDO rate.

\subsubsection{Catalytic Performance of Nickel Phosphide Catalysts in Methyl Palmitate HDO}

Catalytic properties of nickel phosphide catalysts were investigated in the HDO of methyl palmitate $\left(10 \mathrm{wt} \%\right.$ methyl palmitate in $n$-dodecane) in a trickle-bed reactor at a temperature of $290{ }^{\circ} \mathrm{C}$, hydrogen pressure $3.0 \mathrm{MPa}, \mathrm{H}_{2} /$ feed volume ratio $600 \mathrm{Nm}^{3} / \mathrm{m}^{3}$, LHSV of methyl palmitate varied in the interval from 0.3 to $16 \mathrm{~h}^{-1}$. The $\mathrm{X}_{\mathrm{MP}}-\mathrm{LHSV}$ dependencies were obtained to follow the evolution of methyl palmitate (MP), intermediates and the end products in the course of the reaction. The reaction rates normalized per gram of catalysts $\left(\mathrm{A}_{\mathrm{HDO}}\right)$ and per metal sites $(\mathrm{TOF})$ were calculated at the MP conversion level about 15-20\% (for details see Section 3.3).

The catalytic properties of silica-supported Ni phosphide catalysts with different initial $\mathrm{Ni} / \mathrm{P}$ molar ratio and Ni content are summarized in Table 2. The comparison of the rate of MP transformation $\left(\mathrm{A}_{\mathrm{HDO}}\right)$ over two sets of catalysts let us see that $\mathrm{A}_{\mathrm{HDO}}$ is lower over the high-loaded sample with the same Ni/P ratio. Decreasing of Ni/P molar ratio favors increasing of $\mathrm{A}_{\mathrm{HDO}}$ over both high- and low-loaded samples (Figure 4). Broad particle size distributions of phosphide phases on the surfaces of high-loaded $h$-Ni2P1, $h$-Ni1P1, and $h$-Ni1P1 samples does not allow us to compare the activity of these catalysts calculated per metal site (TOF.). The TOF were calculated for the samples with nearly the same size of Ni phosphide nanoparticles (l-Ni2P1, l-Ni1P1, and l-Ni1P2). The trend is the same as for $\mathrm{A}_{\mathrm{HDO}}$ - with the decrease of $\mathrm{Ni} / \mathrm{P}$ molar ratio TOF increases visibly from $5.31 \mathrm{~s}^{-1}$ over $l$-Ni2P1 to $10.65 \mathrm{~s}^{-1}$ over $l$-Ni1P1 and $14.3 \mathrm{~s}^{-1}$ over $l$-Ni1P2. The difference in the activities of $l$-Ni2P1 and the other samples can be explained by the difference in the active phase composition $\left(\mathrm{Ni}_{12} \mathrm{P}_{5}\right.$ versus $\left.\mathrm{Ni}_{2} \mathrm{P}\right)$, but both $l$-Ni1P1 and $l$-Ni1P2 samples contain $\mathrm{Ni}_{2} \mathrm{P}$ phase. The main difference between these two samples is the lower $\mathrm{Ni} / \mathrm{P}$ ratio in the $\mathrm{l}-\mathrm{Ni1} \mathrm{P} 2$ samples, while the mean sizes of Ni phosphide particles are similar. In turn, the decrease of $\mathrm{Ni} / \mathrm{P}$ ratio led to the of phosphate groups content on the surface of phosphide catalysts (Figure 3). 
Table 2. Catalytic properties of silica-supported nickel and nickel phosphide catalysts in methyl palmitate HDO. Reaction conditions: $\mathrm{P}_{\mathrm{H} 2}=3.0 \mathrm{MPa}, \mathrm{T}=290{ }^{\circ} \mathrm{C}, \mathrm{H}_{2} /$ feed $=600 \mathrm{Nm}^{3} / \mathrm{Nm}^{3}$, LHSV $=1.5-16.0 \mathrm{~h}^{-1}$.

\begin{tabular}{|c|c|c|c|c|c|}
\hline Catalyst & $\begin{array}{l}\text { Ni/P Molar Ratio } \\
\text { in Precursor }\end{array}$ & XRD Phase & $\begin{array}{c}A_{H D O} \\
\mathrm{~mol} /\left(\mathrm{h} \cdot \mathrm{g}_{\text {of } N i}\right)\end{array}$ & $A_{\text {M.S. }} \cdot 10^{3}, \mathrm{~s}^{-1}$ & $S c_{16}, \%$ \\
\hline$h-\mathrm{Ni}$ & - & $\mathrm{Ni}$ & $8.8 \times 10^{-3}$ & & 12.7 \\
\hline$h$-Ni2P1 & 2 & $\mathrm{Ni}_{12} \mathrm{P}_{5}$ & $3.4 \times 10^{-2}$ & & 28.0 \\
\hline$h$-Ni1P1 & 1 & $\mathrm{Ni}_{2} \mathrm{P}$ & $8.2 \times 10^{-2}$ & & 28.8 \\
\hline$h$-Ni1P2 & 0.5 & $\mathrm{Ni}_{2} \mathrm{P}$ & $1.8 \times 10^{-1}$ & & 32.8 \\
\hline$l-\mathrm{Ni} 2 \mathrm{P} 1$ & 2 & $\mathrm{Ni}_{12} \mathrm{P}_{5}$ & $7.6 \times 10^{-2}$ & 5.31 & 25.8 \\
\hline l-Ni1P1 & 1 & $\mathrm{Ni}_{2} \mathrm{P}$ & $1.4 \times 10^{-1}$ & 10.65 & 32.1 \\
\hline l-Ni1P2 & 0.5 & $\mathrm{Ni}_{2} \mathrm{P}$ & $2.5 \times 10^{-1}$ & 14.33 & 31.5 \\
\hline
\end{tabular}

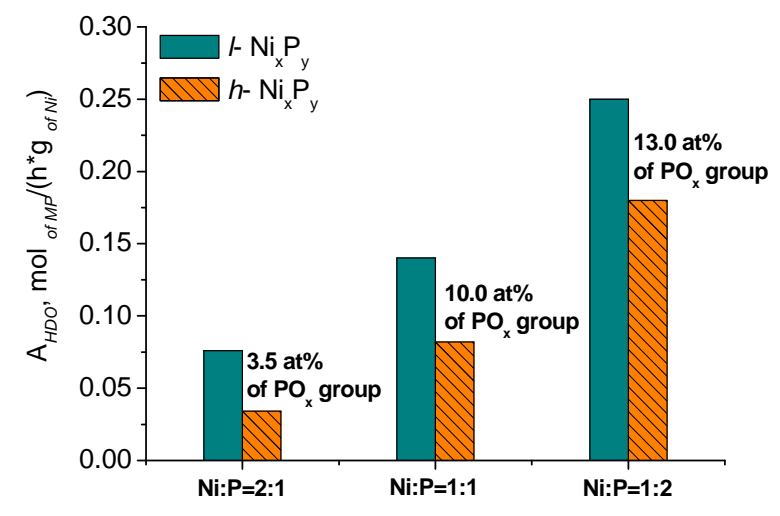

Figure 4. $\mathrm{A}_{\mathrm{HDO}}\left(\mathrm{mol} /(\mathrm{h} \cdot \mathrm{g}\right.$ of $\mathrm{Ni})$ ) versus $\mathrm{PO}_{\mathrm{x}}($ at \%) for the catalysts with different $\mathrm{Ni} / \mathrm{P}$ molar ratios: Ni2P1, Ni1P1, and Ni1P2. Catalytic activity, $\mathrm{A}_{\mathrm{HDO}}$, of $2.5 \mathrm{wt} \% \mathrm{Ni}_{\mathrm{x}} \mathrm{P}_{\mathrm{y}} / \mathrm{SiO}_{2}$ and 7.0 wt $\%$ $\mathrm{Ni}_{x} \mathrm{P}_{\mathrm{y}} / \mathrm{SiO}_{2}$ catalysts prepared with different $\mathrm{Ni}: \mathrm{P}$ molar ratios in methyl palmitate $\mathrm{HDO}$ at the temperature $=290{ }^{\circ} \mathrm{C}$ and hydrogen pressure $=3.0 \mathrm{MPa}$. For the series of $7.0 \mathrm{wt} \% \mathrm{Ni}_{\mathrm{x}} \mathrm{P}_{\mathrm{y}} / \mathrm{SiO}_{2}$ catalysts $\left(h-\mathrm{Ni} 2 \mathrm{P} 1, h-\mathrm{Ni} 1 \mathrm{P} 1\right.$, and $h$-Ni1P2) it was pointed the amount of $\mathrm{PO}_{\mathrm{x}}($ at $\%)$ determined by ${ }^{31} \mathrm{P}$ magic angle-spinning (MAS) nuclear magnetic resonance (NMR).

So, the obtained results have shown the increase of catalytic activity of silica-supported phosphide catalysts in methyl palmitate $\mathrm{HDO}$ with the decrease of $\mathrm{Ni} / \mathrm{P}$ ratio in the sets of catalysts with nearly the same Ni content. This trend coincides with the increase of the $\mathrm{PO}_{\mathrm{x}}$ groups' content percentage observed by NMR in high-loaded samples with the decrease of Ni/P ratio $(3.5,10$ and 13 at $\%$ of the total P content in the $h$-Ni2P1, $h$-Ni1P1, and $h$-Ni1P2). Unfortunately, the quantitative estimation of the amount of $\mathrm{PO}_{\mathrm{x}}$ groups in the low-loaded sample is questionable because of the low intensities of the corresponding signals. But considering the similarity in the phase composition and TPR profile (see Figure S2 in Supplementary Materials) between the low- and high-loaded samples with the close $\mathrm{Ni} / \mathrm{P}$ ratio, we can presume the same trend of $\mathrm{PO}_{\mathrm{x}}$ groups' dependence on $\mathrm{Ni} / \mathrm{P}$ ratio in both sets of catalysts. The evolution of catalytic activity with the $\mathrm{Ni} / \mathrm{P}$ ratio can be explained by the change of the amount of $\mathrm{PO}_{x}$ surface groups, taking into account the tentative scheme of methyl palmitate conversion and the possible role of $\mathrm{PO}_{\mathrm{x}}$ groups that is known to display Brønsted acidity in the $\mathrm{Ni}_{\mathrm{x}} \mathrm{P}_{\mathrm{y}} / \mathrm{SiO}_{2}$ catalysts $[7,26,28,37,42,43]$.

The tentative reaction network of MP transformation over silica-supported Ni phosphide catalysts is considered, taking into account the liquid product distribution, the gas phase analysis and the literature data concerning the HDO of fatty acid ethers [7,10,12-14]. The reaction network of methyl palmitate HDO (Figure 5) has been proposed including several types of reactions which can occur over metal (hydrogenation-dehydrogenation, hydrogenolysis of C-O and C-C bonds) and acid (hydrolysis, esterification, dehydration) active sites [14]. The analysis of product distribution 
depending on LHSV shows that the main products of methyl palmitate HDO are $\mathrm{C}_{15}$ and $\mathrm{C}_{16}$ alkanes, while only minor quantities of intermediate O-containing products, namely palmitic acid, hexadecanal, hexadecanol and palmityl palmitate are detected in all the experiments regardless of the Ni content and $\mathrm{Ni} / \mathrm{P}$ ratio (Figures 6-8). The formation of negligible amounts of $\mathrm{O}$-containing intermediates is confirmed by a minor difference between the conversion of methyl palmitate and overall conversion of oxygen-containing compounds defined by CHNSO elemental analysis (Figure 9). These observations indicate that the oxygen-containing intermediates are transformed further immediately after their production from methyl palmitate, that is, the transformation of methyl palmitate limits of the overall HDO reaction producing $C_{15}$ and $C_{16}$ alkanes as the end products. As a consequence, first of all, the possible routes of methyl palmitate conversion to the intermediates should be analyzed.

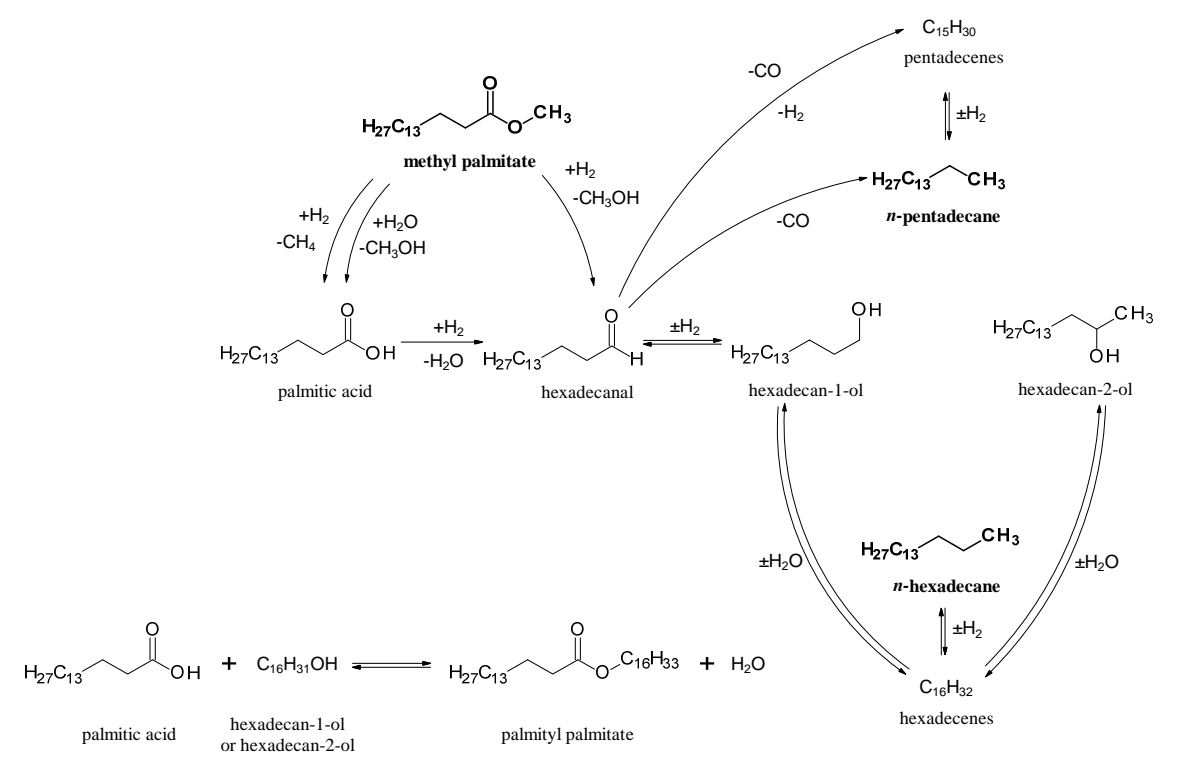

Figure 5. Proposed reaction network over silica-supported nickel phosphide catalysts.

It was proposed in many studies $[2,4,7,10,13,14,45]$ that methyl palmitate transformation proceeds through the formation of palmitic acid or hexadecanal as a primary intermediate (Figure 5). Both possibilities exist for the production of palmitic acid in the HDO of methyl palmitate: via the hydrogenolysis of the $\mathrm{C}-\mathrm{O}$ bond of ester groupover metal sites with the formation of $\mathrm{CH}_{4}$ along with acid or through acid-catalyzed hydrolysis of ester with water leading to the formation of methanol. Hexadecanal can be formed through the direct hydrogenolysis of the C-O $\sigma$-bond of the methyl palmitate carboxylic group leading to hexadecanal and methanol: the second possible way of hexadecanal formation involves hydrogenation of palmitic acid, accompanied with the production of water. Among the listed transformation of methyl palmitate only hydrolysis requires the acid functionality, so the increase of the $\mathrm{PO}_{\mathrm{x}}$ groups amount in the row of catalysts $\mathrm{Ni} 2 \mathrm{P} 1<\mathrm{Ni} 1 \mathrm{P} 1<\mathrm{NiP} 2$ the acceleration of methyl palmitate transformation due to the acid-catalyzed hydrolysis. Several research groups have already reported an increase of Brønsted acid site quantities determined by means of $\mathrm{NH}_{3}$-TPD techniques and assigned to $\mathrm{P}-\mathrm{OH}$ species with the decrease of $\mathrm{Ni} / \mathrm{P}$ ratio in the silica-supported nickel phosphide catalysts $[7,28,37,42,43]$.

In our experiments, the $h-\mathrm{Ni}_{\mathrm{x}} \mathrm{P}_{\mathrm{y}}$ catalysts displayed a higher activity in methyl palmitate HDO that supported $\mathrm{Ni} / \mathrm{SiO}_{2}$ catalyst $\left(\mathrm{D}_{\mathrm{XRD}}=10.7 \mathrm{~nm}\right)$ with nearly the same content of nickel (Figure 10). While $\mathrm{Ni} / \mathrm{SiO}_{2}$ catalyst produces pentadecane with the selectivity about $90 \%$ in all range of the experiments, $\mathrm{SiO}_{2}$ and $\mathrm{PO}_{\mathrm{x}} / \mathrm{SiO}_{2}$ produce only palmitic acid as a result of acid-catalyzed hydrolysis of MP. Additional amount of dodecanol causes the decrease of the rate of MP transformation when HDO of MP and dodecanol mixture was performed over the l-Ni1P2 catalyst (see Figure S3 in Supplementary Materials), pointing out to the competition of dodecanol with the MP molecules 
for the acid sites and testifying the participation of these sites in the MP conversion. The above observations confirm implicitly the important role of acid sites in the methyl palmitate transformation to the intermediates. The analysis of products distribution in the gas phase provides additional information about possible reaction routes of MP and oxygen-containing intermediates transformation. Among the gas phase products of methyl palmitate HDO methane, $\mathrm{CO}$ and some amounts of methanol were observed. The absence of $\mathrm{CO}_{2}$ in the outlet gas indicates that palmitic acid does not produce the $\mathrm{C}_{15}$ hydrocarbons through the decarboxylation $\left(\mathrm{DeCO}_{2}\right)$ route. Further conversion of acid most probably proceeds through the hydrogenation to hexadecanal which in turn gives $n$-pentadecane and $n$-pentadecene through decarbonylation reaction or hexadecanol through hydrogenation reaction. The latter is the main source of $C_{16}$ paraffin via elimination of water from hexadecanol with the formation of hexadecene and subsequent hydrogenation of hexadecene to $n$-hexadecane [15]. Obtained data on selectivity in methyl palmitate HDO correlate well with gas phase data: CO concentration in the gas phase is proportional to n-pentadecane content in the liquid products (see Figure S4 in Supplementary Materials). Authors $[7,12,14]$ reported decarbonylation of methyl laurate (with the formation of undecene) or lauric acid (producing undecanol) but we do not have any evidence that these reactions take place. Moreover, the decarbonylation of palmitic acid should produce alcohol with 15 carbon atoms, but oxygen-containing compounds with 15 carbon atoms in hydrocarbon chain were not detected. Instead, pentadecene was found among the reaction products in small amounts, pointing out to the possibility of hexadecanal decarbonylation producing pentadecene and pentadecane (Figure 5). So, the observed peculiarities make hexadecanal the most probable source of $\mathrm{C}_{15}$ hydrocarbons.

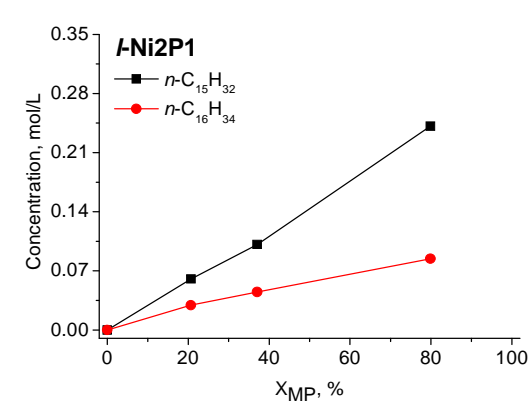

(a)

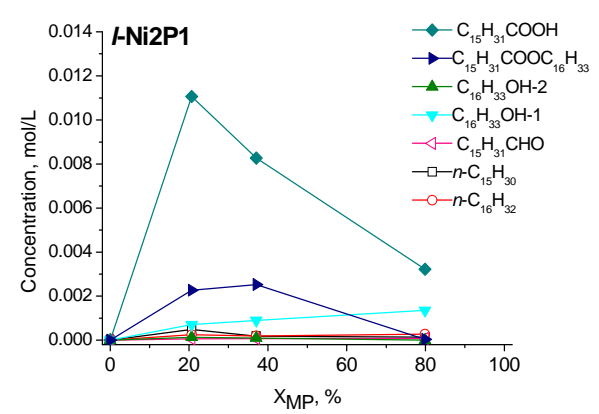

(b)

Figure 6. Concentration profiles of liquid-phase components during methyl palmitate HDO over l-Ni2P1 catalyst: (a) the main products- $\mathrm{C}_{15}$ and $\mathrm{C}_{16}$ hydrocarbons; (b) the observed intermediates. Reaction conditions: $\mathrm{P}_{\mathrm{H} 2}=3.0 \mathrm{MPa}, \mathrm{T}=290^{\circ} \mathrm{C}, \mathrm{H}_{2} /$ feed $=600 \mathrm{Nm}^{3} / \mathrm{Nm}^{3}, \mathrm{LHSV}=0.3-1.5 \mathrm{~h}^{-1}$.

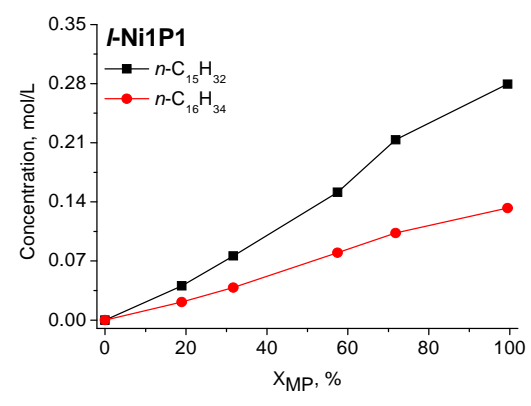

(a)

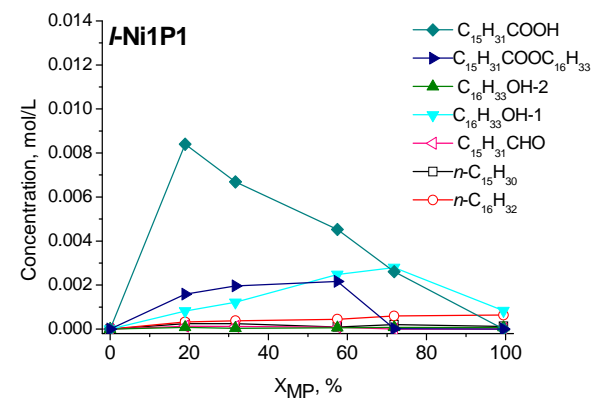

(b)

Figure 7. Concentration profiles of the liquid-phase components during methyl palmitate HDO over l-Ni1P1 catalyst: (a) the main products- $\mathrm{C}_{15}$ and $\mathrm{C}_{16}$ hydrocarbons; (b) the observed intermediates. Reaction conditions: $\mathrm{P}_{\mathrm{H} 2}=3.0 \mathrm{MPa}, \mathrm{T}=290^{\circ} \mathrm{C}, \mathrm{H}_{2} /$ feed $=600 \mathrm{Nm}^{3} / \mathrm{Nm}^{3}$, LHSV $=0.3-3.2 \mathrm{~h}^{-1}$. 


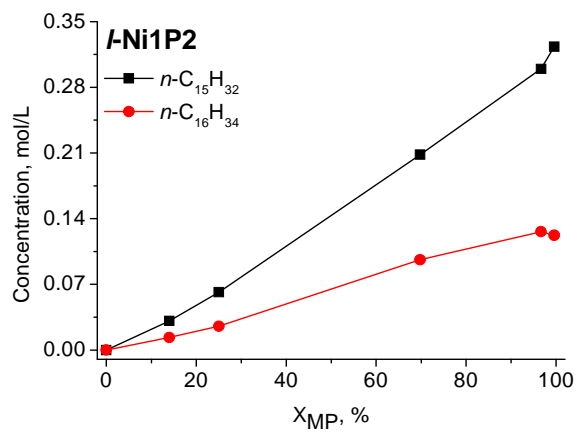

(a)

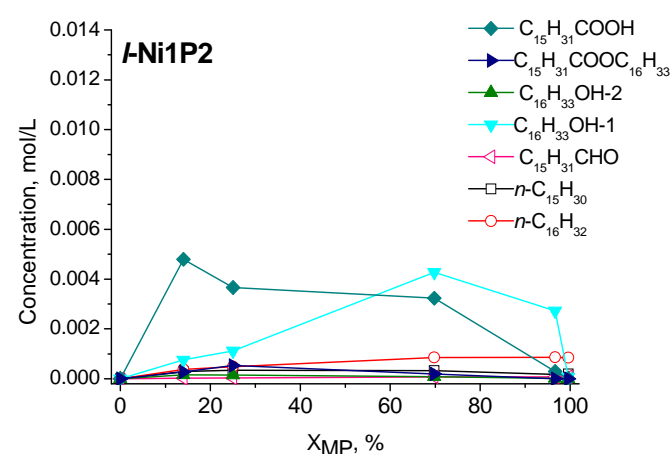

(b)

Figure 8. Concentration profiles of the liquid-phase components during methyl palmitate HDO over l-Ni1P2 catalyst: (a) the main products $-\mathrm{C}_{15}$ and $\mathrm{C}_{16}$ hydrocarbons; $(\mathbf{b})$ the observed intermediates. Reaction conditions: $\mathrm{P}_{\mathrm{H} 2}=3.0 \mathrm{MPa}, \mathrm{T}=290^{\circ} \mathrm{C}, \mathrm{H}_{2} /$ feed $=600 \mathrm{Nm}^{3} / \mathrm{Nm}^{3}, \mathrm{LHSV}=0.3-6.4 \mathrm{~h}^{-1}$.

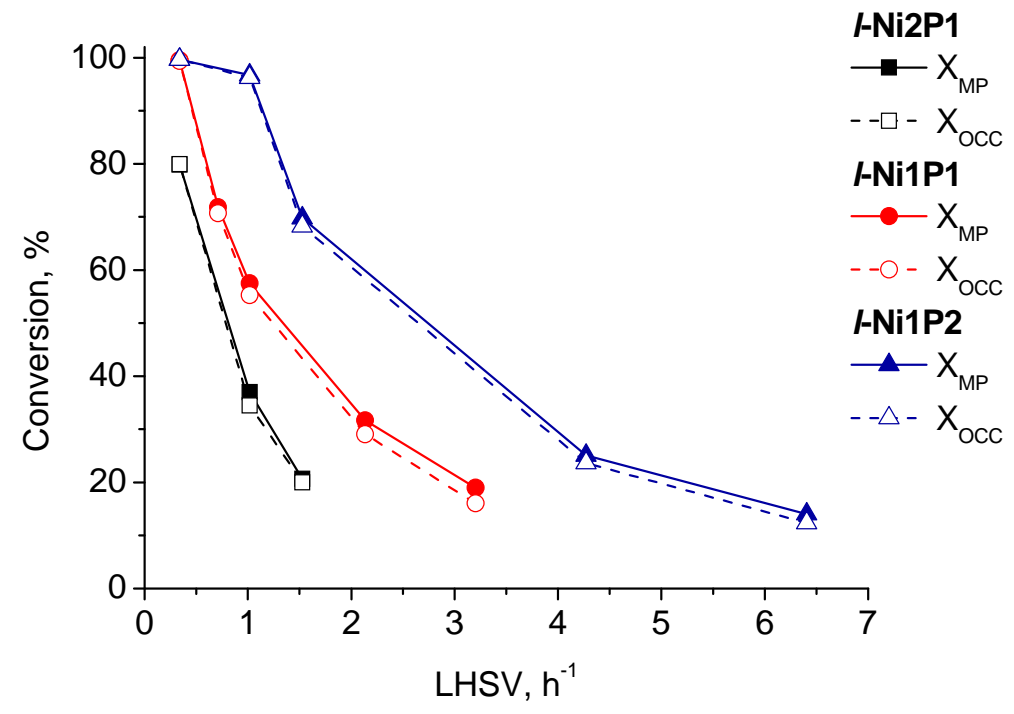

Figure 9. Methyl palmitate $\left(\mathrm{X}_{\mathrm{MP}}\right)$ and oxygen $\left(\mathrm{X}_{\mathrm{OCC}}\right)$ conversions versus liquid hourly space velocity (LHSV) of MP $\left(\mathrm{h}^{-1}\right)$ over the low-loaded nickel phosphide catalysts with different $\mathrm{Ni} / \mathrm{P}$ molar ratios: $l$-Ni2P1, $l$-Ni1P1 and $l$-Ni1P2. Reaction conditions: $\mathrm{P}_{\mathrm{H} 2}=3.0 \mathrm{MPa}, \mathrm{T}=290^{\circ} \mathrm{C}, \mathrm{H}_{2} /$ feed $=600 \mathrm{Nm}^{3} / \mathrm{Nm}^{3}$, LHSV $=0.3-6.4 \mathrm{~h}^{-1}$.

To clarify the routes of acid transformation the additional experiments were done using lauric acid as a model compound. Just only $\mathrm{CO}$ was observed in the exhaust gas of lauric acid HDO over the l-Ni1P2 catalyst, wherein CO does not give methane at least up to $360^{\circ} \mathrm{C}$ (Figure 11). So, methane observed among the product of methyl palmitate HDO can be produced through the methyl palmitate hydrogenolysis or as a result of methanol hydrogenation. The choice between these two contributions is rather complicated since the quantitative analysis of methanol is failed due to its hydrophilicity causing the agglomeration of methanol with the produced water.

Selectivity of methyl palmitate conversion to $C_{15}$ and $C_{16}$ hydrocarbon (at overall oxygen conversion of $100 \%$ ) does not display the evident dependence on the $\mathrm{Ni} / \mathrm{P}$ ratio (Table 2), indicating the minor effect of the phosphate groups on the $C_{16} / C_{15}$ selectivity. The most active $h$-Ni1P2 catalysts demonstrated stable behavior in the time-on-stream experiments at least for $15 \mathrm{~h}$ (see Figure S5 in Supplementary Materials). 


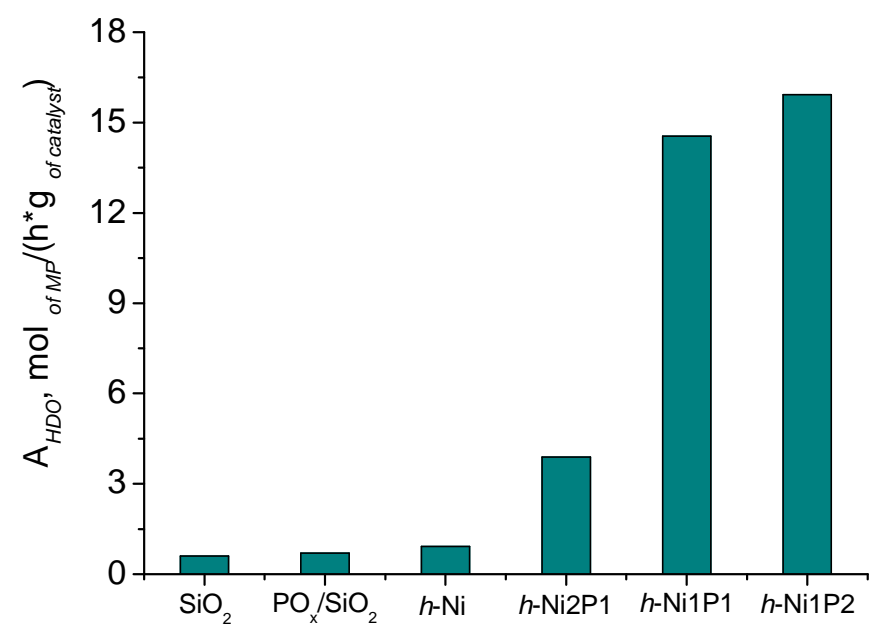

Figure 10. Evolution of the $\mathrm{A}_{\mathrm{HDO}}\left(\mathrm{mol}_{\text {of } \mathrm{MP}} / \mathrm{h} \cdot \mathrm{g}_{\text {of catalyst }}\right.$ ) with the nature of the catalyst: $h$-Ni, $h$-Ni2P1, $h$-Ni1P1, $h$-Ni1P2 and the reference samples $\mathrm{SiO}_{2}$ and $\mathrm{PO}_{\mathrm{x}} / \mathrm{SiO}_{2}$. Reaction conditions: $\mathrm{P}_{\mathrm{H} 2}=3.0 \mathrm{MPa}$, $\mathrm{T}=290{ }^{\circ} \mathrm{C}, \mathrm{H}_{2} /$ feed $=600 \mathrm{Nm}^{3} / \mathrm{Nm}^{3}, \mathrm{LHSV}=0.3-6.4 \mathrm{~h}^{-1}$.

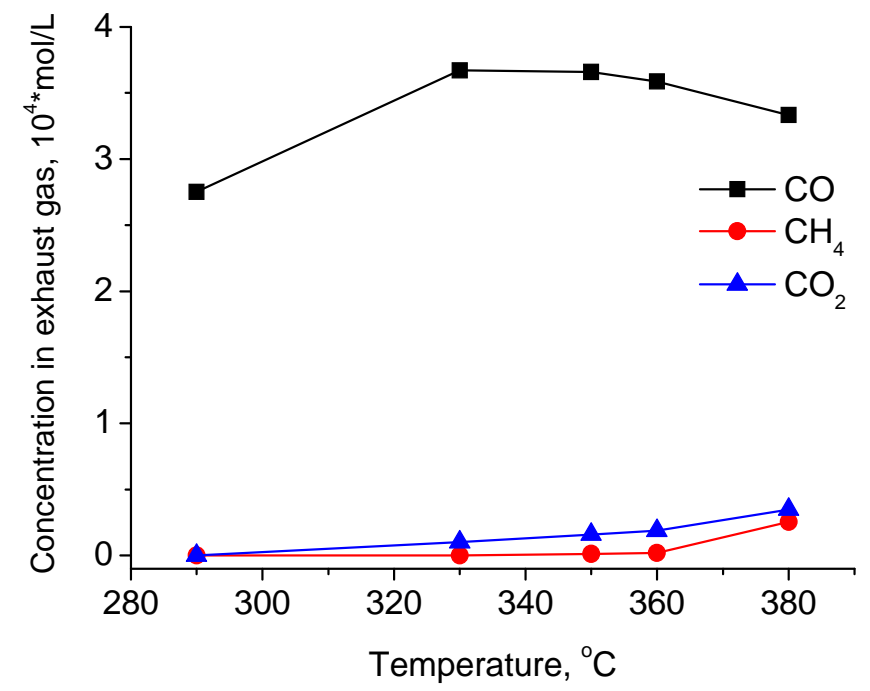

Figure 11. Temperature dependence of the exhaust gas composition during lauric acid HDO over l-Ni1P2 catalyst. Reaction conditions: feed composition $7.41 \mathrm{wt} \%$ lauric acid in $n$-octane, $\mathrm{P}_{\mathrm{H} 2}=3.0 \mathrm{MPa}$, $\mathrm{T}=290-380{ }^{\circ} \mathrm{C}, \mathrm{H}_{2} /$ feed $=600 \mathrm{Nm}^{3} / \mathrm{Nm}^{3}, \mathrm{LHSV}=2.16 \mathrm{~h}^{-1}$.

\section{Materials and Methods}

\subsection{Catalyst Preparation}

Commercial spherical silica «KSKG» (Salavat, Russia, pore volume $-0.80 \mathrm{~cm}^{3} / \mathrm{g}$, average pore diameter-10.6 nm) was purchased from «ChromAnalit» Ltd. (Moscow, Russia) and has been used as a support. Prior to use, the silica was dried at $110{ }^{\circ} \mathrm{C}$ for $7 \mathrm{~h}$ and calcined at $500{ }^{\circ} \mathrm{C}$ for $4 \mathrm{~h}$. Afterwards, it was crushed and sieved to $0.25-0.50 \mathrm{~mm}$.

$\mathrm{Ni}_{x} \mathrm{P}_{y} / \mathrm{SiO}_{2}$ catalysts synthesis. The silica-supported nickel phosphide catalysts were prepared by temperature-programmed reduction (TPR) of nickel- and phosphate-containing precursors, with varying initial $\mathrm{Ni} / \mathrm{P}$ molar ratio, namely $2 / 1,1 / 1$ and $1 / 2$ (samples were denoted as Ni2P1, Ni1P1, and Ni1P2, correspondingly). The optimal reduction conditions for the $\mathrm{Ni}_{2} \mathrm{P} / \mathrm{SiO}_{2}$ catalysts prepared from the nickel phosphate precursors were chosen according to the earlier results [15] and were stated to $600{ }^{\circ} \mathrm{C}$ for $1 \mathrm{~h}$ The initial amount of nickel precursor in the impregnated solution for synthesized 
catalyst was $2.1 \times 10^{-3} \mathrm{~mol}$ of Ni per gram of support for high-loaded samples (denoted as $h$ series) or $5.2 \times 10^{-4} \mathrm{~mol}$ of Ni per gram of support for low-loaded samples (denoted as $l$ series). The procedure for catalyst preparation follows: silica $(0.25-0.50 \mathrm{~mm})$ was incipiently impregnated with an aqueous solution of $\mathrm{Ni}\left(\mathrm{CH}_{3} \mathrm{COO}\right)_{2} \cdot 4 \mathrm{H}_{2} \mathrm{O}$ («Reakhim», Samara, Russia, 99.5\%) and $\left(\mathrm{NH}_{4}\right)_{2} \mathrm{HPO}_{4}$ («Alfa Aesar», Ward Hill, MA, USA, technical grade, $\mathrm{P}_{2} \mathrm{O}_{5} \leq 53 \mathrm{wt} \%$ ) stabilized by nitric acid («Reakhim», Samara, Russia, $70 \mathrm{wt} \%$ ). The impregnated sample was dried at $110{ }^{\circ} \mathrm{C}$ for $4 \mathrm{~h}$ and calcined at $500{ }^{\circ} \mathrm{C}$ for $4 \mathrm{~h}$. The obtained oxide precursor was reduced in hydrogen (flow rate $=150 \mathrm{~mL} / \mathrm{min}$ per gram of precursor) at $600{ }^{\circ} \mathrm{C}\left(\mathrm{ramp}=1{ }^{\circ} \mathrm{C} / \mathrm{min}\right)$ for $1 \mathrm{~h}$ and then cooled to room temperature. Finally, the sample was passivated in $1 \% \mathrm{O}_{2} /$ He flow (flow rate $=80 \mathrm{~mL} / \mathrm{min}$ ) for $2 \mathrm{~h}$ at room temperature.

$\mathrm{Ni} / \mathrm{SiO}_{2}$ catalyst synthesis. The reference $\mathrm{Ni} / \mathrm{SiO}_{2}$ catalyst $(h-\mathrm{Ni})$ was prepared by incipient wetness impregnating of silica granules with an aqueous solution of $\mathrm{Ni}\left(\mathrm{CH}_{3} \mathrm{COO}\right)_{2} \cdot 4 \mathrm{H}_{2} \mathrm{O}$ containing $2.1 \times 10^{-3} \mathrm{~mol}$ of Ni per gram of support, followed by drying at $110^{\circ} \mathrm{C}$ for $4 \mathrm{~h}$ and then calcined at $500{ }^{\circ} \mathrm{C}$ for $4 \mathrm{~h}$. The precursor was reduced by TPR in $\mathrm{H}_{2}$ flow (flow rate $=60 \mathrm{~mL} / \mathrm{min}$ ) at $400{ }^{\circ} \mathrm{C}$ (ramp $=1{ }^{\circ} \mathrm{C} / \mathrm{min}$ ) for $4 \mathrm{~h}$ to obtain $\mathrm{Ni} / \mathrm{SiO}_{2}$ catalyst. Finally, the sample was passivated in $1 \% \mathrm{O}_{2} / \mathrm{He}$ flow (flow rate $=80 \mathrm{~mL} / \mathrm{min}$ ) for $2 \mathrm{~h}$ at room temperature.

The $\mathrm{PO}_{x} / \mathrm{SiO}_{2}\left(h-P_{\text {ox }}\right)$ reference sample was prepared by impregnating of silica with an aqueous solution of $\left(\mathrm{NH}_{4}\right)_{2} \mathrm{HPO}_{4}\left(4.2 \times 10^{-3} \mathrm{~mol}\right.$ of $\mathrm{P}$ per gram of support), followed by drying at $110^{\circ} \mathrm{C}$ for $4 \mathrm{~h}$ and calcination at $500{ }^{\circ} \mathrm{C}$ for $4 \mathrm{~h}$ Prior to use in hydrodeoxygenation, the precursor was activated by standard TPR procedure by heating in $\mathrm{H}_{2}$ flow at $600^{\circ} \mathrm{C}$ for $1 \mathrm{~h}$.

\subsection{Catalyst Characterization}

The elemental analysis of the catalysts was performed using inductively coupled plasma atomic emission spectroscopy (ICP-AES) on Optima 4300 DV (Perkin Elmer, Villebon-sur-Yvette, France).

The textural properties of the catalysts were determined using nitrogen physisorption at $77 \mathrm{~K}$ with an ASAP 2400 instrument (USA).

XRD measurements were performed on an X-ray diffractometer Bruker D8 Advance (Bruker, Karlsruhe, Germany) using $\mathrm{CuK}_{\alpha}$ radiation (wavelength $\lambda=1.5418 \AA$ ) in the $2 \theta$ scanning range of $10^{\circ}-70^{\circ}$. The qualitative phase analysis was carried out using the JCPDS data base [46]. The quantitative phase analysis and refining of the unit cell parameters were carried out by Rietveld analysis of a diffraction pattern using X'Pert High Score Plus software. The average crystallite size $\left(D_{X R D}\right)$ was calculated using the Scherrer equation applied to the (312) reflection at $2 \theta=48.9^{\circ}$ of $\mathrm{Ni}_{12} \mathrm{P}_{5}$ phase and to the (111) reflection at $2 \theta=40.6^{\circ}$ of $\mathrm{Ni}_{2}$ Pphase correspondingly. The average crystallite size $\left(\mathrm{D}_{\mathrm{XRD}}\right)$ of $\mathrm{Ni}_{12} \mathrm{P}_{5}$ nanoparticles was calculated using the Scherrer equation applied to the (312) reflection at $2 \theta=48.9^{\circ}$.

The samples were investigated using high-resolution transmission electron microscopy with a JEM-2010 transmission electron microscope (JEOL, Tokyo, Japan) with accelerating voltage of $200 \mathrm{kV}$ and resolution of $0.14 \mathrm{~nm}$. The local elemental composition was analyzed with an energy-dispersive EDX spectrometer equipped with a $\mathrm{Si}(\mathrm{Li})$ detector (energy resolution-130 eV). To obtain statistical information, the structural parameters of ca. 500 particles were measured. To determine the mean particles diameter $\left(D_{s}\right)$, the Sauter mean diameter was used calculated by the equation:

$$
D_{S}=\frac{\sum n_{i} d_{i}^{3}}{\sum n_{i} d_{i}^{2}}
$$

where $n_{i}$ is the number of particles, $d_{i}$ is the diameter of the $i$ th particle.

The samples of the catalyst precursors were characterized by the $\mathrm{H}_{2}$ temperature-programmed reduction method $\left(\mathrm{H}_{2}-\mathrm{TPR}\right)$. An amount of $0.10 \mathrm{~g}$ of the calcined sample was loaded into a quartz U-tube reactor (inner diameter equal to $4 \mathrm{~nm}$ ). The experiments were carried out in $10 \mathrm{vol} \% \mathrm{H}_{2} / \mathrm{Ar}$ flow (flow rate $=60 \mathrm{~mL} / \mathrm{min}$ ) at heating rate $10{ }^{\circ} \mathrm{C} / \mathrm{min}$ in a temperature region from 80 to $900{ }^{\circ} \mathrm{C}$. 
The $\mathrm{H}_{2}$ consumption was determined by a thermal conductivity detector (TCD). A cold trap $\left(-60^{\circ} \mathrm{C}\right)$ before the TCD was used in order to remove water from exhaust gas.

NMR experiments were carried out using a Bruker Avance- 400 spectrometer at the resonance frequency of $161.923 \mathrm{MHz}$ for ${ }^{31} \mathrm{P}$. Magic Angle Spinning (MAS) spectra were measured using a Bruker MAS NMR probe with 4-mm (outer diameter) $\mathrm{ZrO}_{2}$ rotors at spinning frequency of $14 \mathrm{kHz}$. The ${ }^{31} \mathrm{P}$ spectra were obtained using Hahn-echo sequence using a train of $\pi / 2-\tau-\pi$ pulses, the duration of $\pi / 2$ was $2.4 \mu \mathrm{s}$. The interpulse delay $\tau$ was chosen with respect to the rotation frequency. The sequence repetition delay was $100 \mathrm{~ms}$ due to very short ${ }^{31} \mathrm{P}$ relaxation time in Ni-P intermetallic compounds [47]. Due to very large spectra width, all spectra were collected by frequency stepped technique with a step of $600 \mathrm{ppm}$ (with respect to ${ }^{31} \mathrm{P}$ NMR frequency, $100 \mathrm{kHz}$ ) covering $~ 5000-6000 \mathrm{ppm}$ spectral width, the details can be found elsewhere [48]. The spectra were collected at room temperature and referenced to $85 \%$ water solution of orthophosphoric acid (for ${ }^{31} \mathrm{P}$ experiments). The accuracy of the chemical shift was $\pm 0.5 \mathrm{ppm}$. The number of transients was $16 \mathrm{k}$ in each frequency point. To avoid reduced catalyst oxidation by air, all samples were sealed in glass ampoules without oxygen access. Prior to NMR experiments, the catalysts were transferred from ampoule to NMR rotor in a glove box under argon atmosphere. This technique helps to minimize possible oxidation during NMR spectra acquisition.

\subsection{Experimental Setup and Procedure}

Methyl palmitate («Sigma-Aldrich», St. Louis, MO, USA, grade $\geq 97 \%$ ), lauric acid («Sigma-Aldrich», St. Louis, MO, USA, grade $\geq 98 \%$ ), dodecanol-1 («Sigma-Aldrich», St. Louis, MO, USA, grade $\geq 98 \%$ ), $n$-dodecane («Acros Organics», New Jersey, USA, grade $\geq 99 \%$ ) and $n$-octane («Kriokhrom», Saint Peterburg, Russia, grade $\geq 99.5 \%$ ) were used for initial reaction mixtures preparation.

The catalytic activity in HDO of the methyl palmitate was evaluated in the trickle-bed reactor (inner diameter $9 \mathrm{~mm}$ and total length $265 \mathrm{~mm}$ ) at the temperature $290^{\circ} \mathrm{C}$, hydrogen pressure $3.0 \mathrm{MPa}$, $\mathrm{H}_{2} /$ feed volume ratio $600 \mathrm{Nm}^{3} / \mathrm{Nm}^{3}$, LHSV of MP was varied from 0.3 to $16 \mathrm{~h}^{-1}$. The composition of the reaction mixture, wt \%: methyl palmitate-10 (oxygen content- $1.183 \mathrm{wt} \%$ ), $n$-octane (used as an internal standard for quantification of liquid product) -2 and the rest- $n$-dodecane. The catalyst was placed in the middle part of the reactor between two layers of silicon carbide-inert material with high thermal conductivity, a layer of fine particles of catalyst diluted $(0.2 \div 0.3 \mathrm{~mm})$ silicon carbide in a ratio 1:4 to improve the wettability and uniformity of the liquid distribution in the catalyst layer, minimizing the effect of the wall surface and axial flow heterogeneity. Prior to the reaction, the passivated catalyst was re-reduced in situ in hydrogen (flow rate $=60 \mathrm{ml} / \mathrm{min}$ ) at $400{ }^{\circ} \mathrm{C}$ and hydrogen pressure $5.0 \mathrm{MPa}$ for $15 \mathrm{~h}$. The liquid products were collected every hour till steady-state condition, and time on stream was not less than $8 \mathrm{~h}$.

The conversion of methyl palmitate $\left(X_{M P}\right)$, conversion of oxygen-containing compounds $\left(X_{O C C}\right)$ and the selectivity to $C_{16}$ hydrocarbons $\left(S_{C 16}\right)$ were calculated as follows:

$$
\begin{gathered}
X_{M P}=\left(1-\frac{n_{M P}}{n_{M P}^{o}}\right) \times 100, \% \\
X_{O C C}=\left(1-\frac{n_{O}}{n_{O}^{o}}\right) \times 100, \% \\
S_{C 16}=\left(\frac{n_{C 16}}{n_{M P}^{o}-n_{M P}}\right) \times 100, \%
\end{gathered}
$$

where $n_{M P}^{\circ}$ and $n_{M P}$ are the initial and the current methyl palmitate content in the reaction mixture expressed in mols, $n_{O}^{\circ}$ and $n_{O}$ are the initial and current oxygen content in the reaction mixture expressed in mols, $n_{C 16}$ is the amount of $C_{16}$ hydrocarbons in the products at $X_{M P}=100 \%$ expressed in mols. 
The apparent catalytic activity $\left(A_{H D O}\right)$ of the samples in methyl palmitate HDO was evaluated as follows:

$$
A_{H D O}=\frac{X_{O C C} \cdot F}{\omega_{c a t} \cdot C_{N i}}, \frac{m o l}{g \cdot h}
$$

where $X_{O C C}$ is the conversion of oxygen-containing compounds (\%), $F$ is the molar rate of methyl palmitate fed into the reactor $\left(\mathrm{mol} \cdot \mathrm{h}^{-1}\right), \omega_{c a t}$ is the catalyst weight $(\mathrm{g})$ and $C_{N i}$ is the nickel content in the catalyst (wt \%). $A_{H D O}$ was calculated at the MP conversion below $20 \%$.

The HDO activity (TOF.) of the samples per metal site was estimated by the equation:

$$
T O F=\frac{X_{M P} \cdot F}{\omega_{c a t} \cdot C_{M . S}}, \frac{1}{s}
$$

where $X_{M P}$ is the conversion of methyl palmitate $(\%), F$ is the molar rate of methyl palmitate $\left(\mathrm{mol} \cdot \mathrm{s}^{-1}\right)$, $\omega_{\text {cat }}$ is the catalyst weight $(\mathrm{g})$ and $C_{M . S}$. is the theoretical metal site concentration [49] (mol.g $\mathrm{g}^{-1}$ ) calculated assuming cubic or spherical geometry of nickel phosphide particles uniformly distributed on the surface as follows:

$$
C_{\text {M.S. }}=\frac{6 \cdot \eta \cdot C_{N i_{x} P_{y}}}{\rho_{N i_{x} P_{y}} \cdot D_{S}}, \frac{m o l}{g}
$$

in which $\eta$ is surface metal atom density, $\rho_{N i x P y}$ is the bulk density of $\mathrm{Ni}_{\mathrm{x}} \mathrm{P}_{\mathrm{y}}$ phase (Table 3 ) and $D_{S}$ is the Sauter mean particles diameter obtained from TEM measurements, $C_{N i x P y}$ is the fractional weight loading of nickel phosphide in the catalyst $\left(\omega_{N i x P y} / \omega_{c a t}\right)$. The theoretical metal atom site concentration is an approximate parameter.

Table 3. Surface metal density and bulk density of nickel and nickel phosphide.

\begin{tabular}{ccc}
\hline Compound & Surface Metal Density, $\boldsymbol{\eta}\left(\right.$ Atoms $\left.\cdot \mathbf{c m}^{-2}\right)$ & Compound Density, $\boldsymbol{\rho}\left(\mathbf{g} \cdot \mathbf{c m}^{-\mathbf{3}}\right)$ \\
\hline $\mathrm{Ni}_{2} \mathrm{P}$ & $1.01 \times 10^{15}[49]$ & $7.35[50]$ \\
$\mathrm{Ni}_{12} \mathrm{P}_{5}$ & $1.21 \times 10^{15}$ & $7.53[50]$ \\
\hline
\end{tabular}

\subsection{Products Analysis}

The reaction products were identified using a GC/MS technique (Agilent Technologies 7000 GC/MS Triple QQQ GC System 7890A, Santa Clara, CA, USA) with a VF-5MS quartz capillary column $(30 \mathrm{~m} \times 0.25 \mathrm{~mm} \times 0.25 \mu \mathrm{m})$. The liquid samples were analyzed with a gas chromatography system (Agilent 6890N, Santa Clara, CA, USA) equipped with HP-1MS column $(30 \mathrm{~m} \times 0.32 \mathrm{~mm} \times 1.0 \mu \mathrm{m})$ and flame ionization detector (FID). Gaseous phase products were analyzed online with a gas chromatograph (Chromos 1000, Dzerzhinsk, Russia) equipped with a column packed with 80/100 mesh HayeSep ${ }^{\circledR}$ (Sigma-Aldrich, St. Louis, MO, USA) and FID. The concentrations of $\mathrm{CO}$ and $\mathrm{CO}_{2}$ were analyzed in the form of methane after methanation over reduced Pd catalyst at $340{ }^{\circ} \mathrm{C}$. The carbon balance across the reactor for all experiments was $>95 \%$.

The total oxygen content in the reaction mixture was determined using CHNSO elemental analyzer Vario EL Cube (Elementar Analysensysteme GmbH, Hanau, Germany).

\section{Conclusions}

To get a deeper insight into the $\mathrm{Ni} / \mathrm{P}$ effect on the catalytic properties of silica-supported nickel phosphide catalyst in the aliphatic ester $\mathrm{HDO}$ two sets of the $\mathrm{Ni}_{\mathrm{x}} \mathrm{P}_{\mathrm{y}} / \mathrm{SiO}_{2}$ catalysts differing in nickel content were prepared. Both high-loaded and low-loaded set of catalysts contain the samples with the initial $\mathrm{Ni} / \mathrm{P}$ ratios adjusted to $2 / 1,1 / 1$ and $1 / 2$. Set of high-loaded samples $\left(h-\mathrm{Ni}_{\mathrm{x}} \mathrm{P}_{\mathrm{y}} / \mathrm{SiO}_{2}\right)$ provides a reliable insight into the evolution of the active phase with the $\mathrm{Ni} / \mathrm{P}$ decrease, while the set of low-loaded samples $\left(l-\mathrm{Ni}_{\mathrm{x}} \mathrm{P}_{\mathrm{y}} / \mathrm{SiO}_{2}\right)$ is an appropriate candidate for comparing catalytic behavior 
in the terms of TOF due to the similar value of the mean particle sizes in the catalysts with different $\mathrm{Ni} / \mathrm{P}$ values.

Summarizing the XRD, TEM and NMR results of catalysts characterization it was concluded that the initial $\mathrm{Ni} / \mathrm{P}$ molar ratio influences phase composition of the reduced phosphide catalysts: $\mathrm{Ni}_{2} \mathrm{P}$ produced using the initial $\mathrm{Ni} / \mathrm{P}$ molar ratio of 1 and 0.5 , while the initial Ni/P molar ratio of 2 favors formation of $\mathrm{Ni}_{12} \mathrm{P}_{5}$ phase. According to TEM data have shown the high-loaded samples ( $h$-Ni2P1, $h$-Ni1P1, and $h$-Ni1P2) was shown with TEM contain phosphide particles with the broad particle size distribution (from 2 to $20 \mathrm{~nm}$ ), while uniformly distributed phosphide particles with the mean particle diameter $4.9 \mathrm{~nm}$ for $l-\mathrm{Ni} 2 \mathrm{P} 1), 4.7 \mathrm{~nm}$ for $l$-Ni1P1 and $3.5 \mathrm{~nm}$ for $l$-Ni1P2 were observed. ${ }^{31} \mathrm{P}$ MAS NMR results showed that an increase of $\mathrm{Ni} / \mathrm{P}$ ratio is accompanied by the increase of the $\mathrm{PO}_{\mathrm{x}}$ groups on the surface of high-loaded samples; the same dependence was speculated for the low-loading samples taking into account the similarities in the active phase composition and TPR behavior.

Catalytic activity in methyl palmitate HDO normalized to metal content was found to increase with the decrease of $\mathrm{Ni} / \mathrm{P}$ content in the catalysts and such dependence was true for both sets of catalysts. The same trend of TOF increase over the $l-\mathrm{Ni}_{x} \mathrm{P}_{\mathrm{y}} / \mathrm{SiO}_{2}$ catalysts was explained by the acceleration of methyl palmitate transformation due to the hydrolysis of methyl palmitate over acid $\mathrm{PO}_{\mathrm{x}}$ groups of the nickel phosphide catalysts. The obtained dependence corroborates our previous results, where the increase of phosphate groups content through the adjusting of phosphorus precursor and reduction temperature provides the increase of methyl palmitate conversion rate in HDO [15].

The decrease of $\mathrm{Ni} / \mathrm{P}$ ratio in the silica-supported nickel phosphide catalysts was shown to increase the rate of methyl palmitate conversion most probably through the hydrolysis of methyl palmitate over acid sites presented by the phosphate groups of the silica-supported nickel phosphide catalysts. Thus, the employment of support with the pronounced acidity for the preparation of supported phosphide catalysts can significantly increase the rate of fatty ether HDO and alkane production. However, the appropriate balance of acid and metal functionalities is crucial to provide the high catalytic activity of phosphide catalysts in the overall reaction of methyl palmitate HDO, comprising the variety of acid-catalyzed and metal-catalyzed reactions.

Supplementary Materials: The following are available online at www.mdpi.com/2073-4344/7/10/298/s1. Figure S1: TEM images of $\mathrm{Ni}_{\mathrm{x}} \mathrm{P}_{\mathrm{y}} / \mathrm{SiO}_{2}$ catalysts with different initial molar Ni/P ratio: (a) $l$-Ni2P1; (b) $l$-Ni1P1; (c) $l$-Ni1P2, Figure S2: $\mathrm{H}_{2}$-TPR profiles of $\mathrm{Ni}_{\mathrm{x}} \mathrm{P}_{\mathrm{y}} / \mathrm{SiO}_{2}$ catalyst oxide precursors with different nickel phosphide loading: $h$-Ni1P2 and $l$-Ni1P2, Figure S3: Effect of the dodecanol additive on methyl palmitate conversion during HDO over $l$-Ni1P2 catalyst. Feed composition: mixture $1-10.0 \mathrm{wt} \% \mathrm{MP}$ in $n$-octane; mixture $2-10.0 \mathrm{wt} \% \mathrm{MP}$ and $5 \mathrm{wt} \% \mathrm{C}_{12} \mathrm{H}_{25} \mathrm{OH}$ in $n$-octane. Reaction conditions: $\mathrm{P}_{\mathrm{H} 2}=3.0 \mathrm{MPa}, \mathrm{T}=290{ }^{\circ} \mathrm{C}, \mathrm{H}_{2} /$ feed $=600 \mathrm{Nm}^{3} / \mathrm{Nm}^{3}, \mathrm{LHSV}$ of $M P=1.02 \mathrm{~h}^{-1}$, Figure S4: $n$-Pentadecane concentration in liquid phase versus CO concentration in exhaust gas phase during palmitic acid HDO over $l$-Ni1P2 catalyst. Reaction conditions: feed composition $5.0 \mathrm{wt} \%$ palmitic acid in $n$-dodecane, $\mathrm{P}_{\mathrm{H} 2}=3.0 \mathrm{MPa}, \mathrm{T}=290^{\circ} \mathrm{C}, \mathrm{H}_{2} /$ feed $=600 \mathrm{Nm}^{3} / \mathrm{Nm}^{3}$, LHSV $=0.3-6.4 \mathrm{~h}^{-1}$, Figure S5: Methyl palmitate and oxygen-containing compounds conversions and $\mathrm{C}_{16}$ hydrocarbons selectivity $\left(\mathrm{S}_{\mathrm{C} 16}\right)$ during methyl palmitate HDO over $h$-Ni1P2 catalysts. Reaction conditions: $\mathrm{P}_{\mathrm{H} 2}=3.0 \mathrm{MPa}, \mathrm{T}=290{ }^{\circ} \mathrm{C}, \mathrm{H}_{2} / \mathrm{feed}=600 \mathrm{Nm}^{3} / \mathrm{Nm}^{3}$, LHSV $=10.7 \mathrm{~h}^{-1}$.

Acknowledgments: This work was conducted within the framework of budget project No. 0303-2016-0012 for Boreskov Institute of Catalysis. The authors are grateful to V.A. Rogov for catalysts characterization by $\mathrm{H}_{2}-\mathrm{TPR}$, and to V.A. Utkin and M.V. Shashkov for reaction products identification using GC/MS technique.

Author Contributions: G.A.B. conceived and designed the experiments and supervised the work; I.V.S. performed the catalyst synthesis; I.V.D., I.V.S. and P.V.A. performed the catalytic activity tests; E.Y.G. performed the catalyst characterization by TEM; V.P.P. performed the catalyst characterization by XRD; I.V.Y. and O.B.L. performed the catalyst characterization by MAS NMR; I.V.D., P.V.A., I.V.S. and G.A.B. analyzed the experimental data and wrote the paper.

Conflicts of Interest: The authors declare no conflict of interest. 


\section{References}

1. Kubicka, D.; Tukac, V. Chapter 3. Hydrotreating of Triglyceride Based Feedstocks in Refineries. In Advances in Chemical Engineering, Chemical Engineering for Renewables Conversion, 1st ed.; Murzin, D.Y., Ed.; Academic Press: Cambridge, MA, USA, 2013; Volume 42, pp. 141-194.

2. Senol, O.I.; Viljava, T.R.; Krause, A.O.I. Hydrodeoxygenation of methyl esters on sulphided $\mathrm{NiMo} /$ gamma- $\mathrm{Al}_{2} \mathrm{O}_{3}$ and $\mathrm{CoMo} /$ gamma- $\mathrm{Al}_{2} \mathrm{O}_{3}$ catalysts. Catal. Today 2005, 100, 331-335. [CrossRef]

3. Donnis, B.; Egeberg, R.G.; Blom, P.; Knudsen, K.G. Hydroprocessing of Bio-Oils and Oxygenates to Hydrocarbons. Understanding the Reaction Routes. Top. Catal. 2009, 52, 229-240. [CrossRef]

4. Deliy, I.V.; Vlasova, E.N.; Nuzhdin, A.L.; Gerasimov, E.Yu.; Bukhtiyarova, G.A. Hydrodeoxygenation of methyl palmitate over sulfided $\mathrm{Mo} / \mathrm{Al}_{2} \mathrm{O}_{3}, \mathrm{CoMo} / \mathrm{Al}_{2} \mathrm{O}_{3}$ and $\mathrm{NiMo} / \mathrm{Al}_{2} \mathrm{O}_{3}$ catalysts. RSC Adv. 2014, 4, 2242-2250. [CrossRef]

5. Liu, S.Y.; Zhu, Q.Q.; Guan, Q.X.; He, L.N.; Li, W. Bio-aviation fuel production from hydroprocessing castor oil promoted by the nickel-based bifunctional catalysts. Bioresour. Technol. 2015, 183, 93-100. [CrossRef] [PubMed]

6. Kordulis, C.; Bourikas, K.; Gousi, M.; Kordouli, E.; Lycourghiotis, A. Development of nickel based catalysts for the transformation of natural triglycerides and related compounds into green diesel: A critical review. Appl. Catal. B Environ. 2016, 181, 156-196. [CrossRef]

7. Chen, J.X.; Shi, H.; Li, L.; Li, K.L. Deoxygenation of methyl laurate as a model compound to hydrocarbons on transition metal phosphide catalysts. Appl. Catal. B Environ. 2014, 144, 870-884. [CrossRef]

8. Yang, Y.X.; Ochoa-Hernandez, C.; Pizarro, P.; O'Shea, V.A.D.; Coronado, J.M.; Serrano, D.P. Influence of the $\mathrm{Ni} / \mathrm{P}$ ratio and metal loading on the performance of $\mathrm{Ni}_{\mathrm{x}} \mathrm{P}_{\mathrm{y}} / \mathrm{SBA}-15$ catalysts for the hydrodeoxygenation of methyl oleate. Fuel 2015, 144, 60-70. [CrossRef]

9. Yang, Y.X.; Ochoa-Hernandez, C.; O'Shea, V.A.D.; Coronado, J.M.; Serrano, D.P. Ni $2_{2} P / S B A-15$ As a Hydrodeoxygenation Catalyst with Enhanced Selectivity for the Conversion of Methyl Oleate Into n-Octadecane. ACS Catal. 2012, 2, 592-598. [CrossRef]

10. Guan, Q.X.; Han, F.; Li, W. Catalytic performance and deoxygenation path of methyl palmitate on $\mathrm{Ni}_{2} \mathrm{P} / \mathrm{SiO}_{2}$ synthesized using the thermal decomposition of nickel hypophosphite. RSC Adv. 2016, 6, 31308-31315. [CrossRef]

11. Xue, Y.A.; Guan, Q.X.; Li, W. Synthesis of bulk and supported nickel phosphide using microwave radiation for hydrodeoxygenation of methyl palmitate. RSC Adv. 2015, 5, 53623-53628. [CrossRef]

12. Shi, H.; Chen, J.X.; Yang, Y.; Tian, S.S. Catalytic deoxygenation of methyl laurate as a model compound to hydrocarbons on nickel phosphide catalysts: Remarkable support effect. Fuel Process. Technol. 2014, 118, 161-170. [CrossRef]

13. Guan, Q.X.; Wan, F.F.; Han, F.; Liu, Z.H.; Li, W. Hydrodeoxygenation of methyl palmitate over MCM-41 supported nickel phosphide catalysts. Catal. Today 2016, 259, 467-473. [CrossRef]

14. Yang, Y.; Chen, J.X.; Shi, H. Deoxygenation of Methyl Laurate as a Model Compound to Hydrocarbons on $\mathrm{Ni}_{2} \mathrm{P} / \mathrm{SiO}_{2}, \mathrm{Ni}_{2} \mathrm{P} / \mathrm{MCM}-41$, and $\mathrm{Ni}_{2} \mathrm{P} / \mathrm{SBA}-15$ Catalysts with Different Dispersions. Energy Fuels 2013, 27, 3400-3409. [CrossRef]

15. Shamanaev, I.V.; Deliy, I.V.; Aleksandrov, P.V.; Gerasimov, E.Yu.; Pakharukova, V.P.; Kodenev, E.G.; Ayupov, A.B.; Andreev, A.S.; Lapina, O.B.; Bukhtiyarova, G.A. Effect of precursor on the catalytic properties of $\mathrm{Ni}_{2} \mathrm{P} / \mathrm{SiO}_{2}$ in methyl palmitate hydrodeoxygenation. RSC Adv. 2016, 6, 30372-30383. [CrossRef]

16. Shamanaev, I.V.; Deliy, I.V.; Pakharukova, V.P.; Gerasimov, E.Yu.; Rogov, V.A.; Bukhtiyarova, G.A. Effect of the preparation conditions on the physicochemical and catalytic properties of $\mathrm{Ni}_{2} \mathrm{P} / \mathrm{SiO}_{2}$ catalysts. Russ. Chem. Bull. Int. Ed. 2015, 64, 2361-2370. [CrossRef]

17. Liu, Y.H.; Yao, L.; Xin, H.; Wang, G.S.; Li, D.; Hu, C.W. The production of diesel-like hydrocarbons from palmitic acid over HZSM-22 supported nickel phosphide catalysts. Appl. Catal. B Environ. 2015, 174, 504-514. [CrossRef]

18. Zarchin, R.; Rabaev, M.; Vidruk-Nehemya, R.; Landau, M.V.; Herskowitz, M. Hydroprocessing of soybean oil on nickel-phosphide supported catalysts. Fuel 2015, 139, 684-691. [CrossRef]

19. Lee, S.I.; Jeon, H.J.; Ju, S.J.; Ryu, J.W.; Oh, S.H.; Koh, J.H. Metal Phosphorus Compound for Preparing Biodiesel and Method Preparing Biodiesel Using the Same. Patent US2014/0150332A1, 5 June 2014. 
20. Zhao, S.; Zhang, Z.N.; Zhu, K.Y.; Chen, J.X. Hydroconversion of methyl laurate on bifunctional $\mathrm{Ni}_{2} \mathrm{P} /$ AlMCM-41 catalyst prepared via in situ phosphorization using triphenylphosphine. Appl. Surf. Sci. 2017, 404, 388-397. [CrossRef]

21. Zhang, Z.N.; Tang, M.X.; Chen, J.X. Effects of P/Ni ratio and Ni content on performance of gamma- $\mathrm{Al}_{2} \mathrm{O}_{3}$-supported nickel phosphides for deoxygenation of methyl laurate to hydrocarbons. Appl. Surf. Sci. 2016, 360, 353-364. [CrossRef]

22. Oyama, S.T.; Gott, T.; Zhao, H.Y.; Lee, Y.K. Transition metal phosphide hydroprocessing catalysts: A review. Catal. Today 2009, 143, 94-107. [CrossRef]

23. Sun, F.X.; Wu, W.C.; Wu, Z.L.; Guo, J.; Wei, Z.B.; Yang, Y.X.; Jiang, Z.X.; Tian, F.P.; Li, C. Dibenzothiophene hydrodesulfurization activity and surface sites of silica-supported $\mathrm{MoP}, \mathrm{Ni} 2 \mathrm{P}$, and Ni-Mo-P catalysts. J. Catal. 2004, 228, 298-310. [CrossRef]

24. Bui, P.; Cecilia, J.A.; Oyama, S.T.; Takagaki, A.; Infantes-Molina, A.; Zhao, H.Y.; Li, D.; Rodriguez-Castellon, E.; Lopez, A.J. Studies of the synthesis of transition metal phosphides and their activity in the hydrodeoxygenation of a biofuel model compound. J. Catal. 2012, 294, 184-198. [CrossRef]

25. Rodriguez, J.A.; Vines, F.; Liu, P.; Illas, F. Chapter 6. Role of C and P Sites on the Chemical Activity of Metal Carbides and Phosphides: From Clusters to Single-Crystal Surfaces. In Model Systems in Catalysis: Single Crystals to Supported Enzyme Mimics; Rioux, R.M., Ed.; Springer Science + Business Media: New York, NY, USA, 2010; pp. 117-132.

26. Lee, Y.K.; Oyama, S.T. Bifunctional nature of a $\mathrm{SiO}_{2}$-supported $\mathrm{Ni}_{2} \mathrm{P}$ catalyst for hydrotreating: EXAFS and FTIR studies. J. Catal. 2006, 239, 376-389. [CrossRef]

27. Chen, J.X.; Guo, T.; Li, K.L.; Sun, L.M. A facile approach to enhancing activity of $\mathrm{Ni}_{2} \mathrm{P} / \mathrm{SiO}_{2}$ catalyst for hydrodechlorination of chlorobenzene: Promoting effect of water and oxygen. Catal. Sci. Technol. 2015, 5, 2670-2680. [CrossRef]

28. Abu, I.I.; Smith, K.J. The effect of cobalt addition to bulk $\mathrm{MoP}$ and $\mathrm{Ni}_{2} \mathrm{P}$ catalysts for the hydrodesulfurization of 4,6-dimethyldibenzothiophene. J. Catal. 2006, 241, 356-366. [CrossRef]

29. Stinner, C.; Tang, Z.; Haouas, M.; Weber, T.; Prins, R. Preparation and ${ }^{31}$ P NMR characterization of nickel phosphides on silica. J. Catal. 2002, 208, 456-466. [CrossRef]

30. Sawhill, S.J.; Layman, K.A.; Van Wyk, D.R.; Engelhard, M.H.; Wang, C.; Bussell, M.E. Thiophene hydrodesulfurization over nickel phosphide catalysts: Effect of the precursor composition and support. J. Catal. 2005, 231, 300-313. [CrossRef]

31. Oyama, S.T.; Wang, X.; Lee, Y.K.; Bando, K.; Requejo, F.G. Effect of phosphorus content in nickel phosphide catalysts studied by XAFS and other techniques. J. Catal. 2002, 210, 207-217. [CrossRef]

32. Koranyi, T.I.; Vit, Z.; Nagy, J.B. Support and pretreatment effects on the hydrotreating activity of SBA-15 and CMK-5 supported nickel phosphide catalysts. Catal. Today 2008, 130, 80-85. [CrossRef]

33. Zhao, H.Y.; Li, D.; Bui, P.; Oyama, S.T. Hydrodeoxygenation of guaiacol as model compound for pyrolysis oil on transition metal phosphide hydroprocessing catalysts. Appl. Catal. A Gen. 2011, 391, 305-310. [CrossRef]

34. Prins, R.; Bussell, M. Metal Phosphides: Preparation, Characterization and Catalytic Reactivity. Catal. Lett. 2012, 142, 1413-1436. [CrossRef]

35. Iino, A.; Cho, A.; Takagaki, A.; Kikuchi, R.; Oyama, S.T. Kinetic studies of hydrodeoxygenation of 2-methyltetrahydrofuran on a $\mathrm{Ni}_{2} \mathrm{P} / \mathrm{SiO}_{2}$ catalyst at medium pressure. J. Catal. 2014, 311, 17-27. [CrossRef]

36. Landau, M.V.; Herskowitz, M.; Hoffman, T.; Fuks, D.; Liverts, E.; Vingurt, D.; Froumin, N. Ultradeep Hydrodesulfurization and Adsorptive Desulfurization of Diesel Fuel on Metal-Rich Nickel Phosphides. Ind. Eng. Chem. Res. 2009, 48, 5239-5249. [CrossRef]

37. Wu, S.K.; Lai, P.C.; Lin, Y.C. Atmospheric Hydrodeoxygenation of Guaiacol over Nickel Phosphide Catalysts: Effect of Phosphorus Composition. Catal. Lett. 2014, 144, 878-889. [CrossRef]

38. Liu, X.G.; Chen, J.X.; Zhang, J.Y. Hydrodechlorination of chlorobenzene over silica-supported nickel phosphide catalysts. Ind. Eng. Chem. Res. 2008, 47, 5362-5368. [CrossRef]

39. Bekaert, E.; Bernardi, J.; Boyanov, S.; Monconduit, L.; Doublet, M.L.; Menetrier, M. Direct Correlation between the ${ }^{31} \mathrm{P}$ MAS NMR Response and the Electronic Structure of Some Transition Metal Phosphides. J. Phys. Chem. C 2008, 112, 20481-20490. [CrossRef]

40. Krawietz, T.R.; Lin, P.; Lotterhos, K.E.; Torres, P.D.; Barich, D.H.; Clearfield, A.; Haw, J.F. Solid phosphoric acid catalyst: A multinuclear NMR and theoretical study. J. Am. Chem. Soc. 1998, 120, 8502-8511. [CrossRef] 
41. Eichele, K.; Wasylishen, R.E. ${ }^{31}$ P NMR Study of Powder and Single-Crystal Samples of Ammonium Dihydrogen Phosphate-Effect of Homonuclear Dipolar Coupling. J. Phys. Chem. 1994, 98, 3108-3113. [CrossRef]

42. Chen, J.X.; Sun, L.M.; Wang, R.J.; Zhang, J.Y. Hydrodechlorination of Chlorobenzene Over $\mathrm{Ni}_{2} \mathrm{P} / \mathrm{SiO}_{2}$ Catalysts: Influence of $\mathrm{Ni}_{2} \mathrm{P}$ Loading. Catal. Lett. 2009, 133, 346-353. [CrossRef]

43. Cecilia, J.A.; Infantes-Molina, A.; Rodriguez-Castellon, E.; Jimenez-Lopez, A.; Oyama, S.T. Oxygen-removal of dibenzofuran as a model compound in biomass derived bio-oil on nickel phosphide catalysts: Role of phosphorus. Appl. Catal. B Environ. 2013, 136, 140-149. [CrossRef]

44. Vannice, M.A. Intraphase Gradients (Weisz-Prater Criterion). In Kinetics of Catalytic Reactions; Springer Science + Business Media. Inc.: NewYork, NY, USA, 2005; pp. 63-77.

45. Senol, O.I.; Ryymin, E.M.; Viljava, T.R.; Krause, A.O.I. Reactions of methyl heptanoate hydrodeoxygenation on sulphided catalysts. J. Mol. Catal. A Chem. 2007, 268, 1-8. [CrossRef]

46. JCPDS. International Centre for Diffraction Data; JCPDS: Swarthmore, PA, USA, 1997.

47. Furo, I.; Bakonyi, I.; Tompa, K.; Zsoldos, E.; Heinmaa, I.; Alla, M.; Lippmaa, E. ${ }^{31}$ P Nuclear-MagneticResonance Knight-Shift and Linewidth in $\mathrm{Ni}_{3} \mathrm{P}$ and $\mathrm{Cu}_{3} \mathrm{P}: \mathrm{A}$ Magic-Angle Spinning Study. J. Phys. Condens. Mat. 1990, 2, 4217-4225. [CrossRef]

48. Andreev, A.S.; de Lacaillerie, J.B.D.; Lapina, O.B.; Gerashenko, A. Thermal stability and hcp-fcc allotropic transformation in supported Co metal catalysts probed near operando by ferromagnetic NMR. Phys. Chem. Chem. Phys. 2015, 17, 14598-14604. [CrossRef] [PubMed]

49. Wang, X.Q.; Clark, P.; Oyama, S.T. Synthesis, characterization, and hydrotreating activity of several iron group transition metal phosphides. J. Catal. 2002, 208, 321-331. [CrossRef]

50. Ren, J.; Wang, J.-G.; Li, J.-F.; Li, Y.-W. Density functional theory study on crystal nickel phosphides. J. Fuel Chem. Technol. 2007, 35, 458-464. [CrossRef]

(C) 2017 by the authors. Licensee MDPI, Basel, Switzerland. This article is an open access article distributed under the terms and conditions of the Creative Commons Attribution (CC BY) license (http:/ / creativecommons.org/licenses/by/4.0/). 